\title{
Determining Optimal Dry Port Location for Seaport Rijeka Using AHP Decision-Making Methodology
}

\author{
Josip Božičević ${ }^{1}$, Ivica Lovrić ${ }^{2}$, Dajana Bartulović ${ }^{3, *(\mathbb{D})}$, Sanja Steiner ${ }^{4}$, Violeta Roso ${ }^{5}$ \\ and Jasmina Pašagić Škrinjar ${ }^{6}$ \\ 1 Croatian Academy of Sciences and Arts, 10000 Zagreb, Croatia; bozicevic@hazu.hr \\ 2 City of Zagreb, 10000 Zagreb, Croatia; ivica.lovric@zagreb.hr \\ Institute of Traffic and Communications, 10000 Zagreb, Croatia \\ Traffic Institute, Croatian Academy of Sciences and Arts, 10000 Zagreb, Croatia; ssteiner@hazu.hr \\ 5 Department of Technology Management and Economics, Chalmers University of Technology, \\ SE-412 96 Gothenburg, Sweden; violeta.roso@chalmers.se \\ 6 Department of Transportation Logistics, Faculty of Traffic and Transport Sciences, University of Zagreb, \\ 10000 Zagreb, Croatia; jpasagic@fpz.unizg.hr \\ * Correspondence: dbartulovic@gmail.com
}

check for updates

Citation: Božičević, J.; Lovrić, I.; Bartulović, D.; Steiner, S.; Roso, V.; Pašagić Škrinjar, J. Determining Optimal Dry Port Location for Seaport Rijeka Using AHP Decision-Making Methodology. Sustainability 2021, 13, 6471. https://doi.org/10.3390/ su13116471

Academic Editor: Maxim A. Dulebenets

Received: 15 April 2021

Accepted: 3 June 2021

Published: 7 June 2021

Publisher's Note: MDPI stays neutral with regard to jurisdictional claims in published maps and institutional affiliations.

Copyright: (c) 2021 by the authors. Licensee MDPI, Basel, Switzerland. This article is an open access article distributed under the terms and conditions of the Creative Commons Attribution (CC BY) license (https:// creativecommons.org/licenses/by/ $4.0 /)$.

\begin{abstract}
Seaport Rijeka is located and connected to the strategic EU TEN-T transport routes (Mediterranean and Baltic-Adriatic Corridor). Seaport Rijeka represents the shortest connection between Central and Central-Eastern Europe, and overseas destinations, by land and sea, and is in an excellent position to take advantage of its location. Being the largest and busiest seaport in Croatia, with constant increase in cargo traffic, especially container traffic, with inadequate and incomplete transport infrastructure that creates congestion, Seaport Rijeka will soon reach its capacity limits. One of the possible solutions that would satisfy the increasing demand and mitigate existing problems is establishing a dry port. Establishing a dry port serving Seaport Rijeka on the EU transport routes would greatly contribute to the strategic and operational plans of the EU and Croatia. The focus of this paper is to determine the optimal dry port location for Seaport Rijeka. The AHP methodology was used to determine the optimal dry port location of the Seaport Rijeka, by analyzing a large set of influential factors. The analysis was performed for three groups of possible dry port locations (close, medium distance and distant). Results suggest that optimal dry port locations for Seaport Rijeka are in Miklavlje, Velika Gorica and Vinkovci.
\end{abstract}

Keywords: dry port; location; seaport; optimal; decision-making; AHP methodology

\section{Introduction}

Due to previous research related to the importance of establishing and implementing a dry port in Croatia, and all its advantages, this paper addresses and evaluates the current state of transport network development in Croatia, with a particular emphasis on the Seaport Rijeka and its role and importance in further transport network development in Croatia. The current status of Seaport Rijeka, with respect to its connection to the Croatian and EU transport network, is elaborated and evaluated. Being the largest and busiest seaport in Croatia, with constant increase in cargo traffic, especially container traffic, with inadequate and incomplete transport infrastructure that creates congestion, Seaport Rijeka will soon reach its capacity limits. Seaport Rijeka is located on the strategic EU transport route (TEN-T Mediterranean Corridor) and is connected to the Baltic-Adriatic Corridor [1] Due to its favorable position, Seaport Rijeka represents the shortest connection between Central and Central-Eastern Europe, and overseas destinations, by land and sea, and is in an excellent position to take advantage of its location.

Seaport Rijeka is searching for solutions to expand. One of the possible solutions that would satisfy the increasing demand is establishing a dry port [2]. Dry ports have 
many advantages, faster transport of cargo from seaports, use of more efficient modes of transport, providing facilities for the storage and consolidation of goods, the maintenance of road or rail freight carriers, customs services, etc. [2-11]. Establishing a dry port serving Seaport Rijeka on the EU transport routes would greatly contribute to the strategic and operational plans of the EU and Croatia.

In order to determine the optimal location of a new dry port, it is necessary to determine the set of essential influential factors impacting the establishment of a new dry port. By detailed analysis and study, the authors have created a set of all influential factors for the establishment of a new dry port. Defined influential factors are divided into eight groups: technical, technological, organizational, ecological, information and communication (IT), economic, legal and regulatory, and specific. The selection of the dry port location depends on all of the influential factors.

The AHP methodology was used to determine the optimal dry port location of the Seaport Rijeka, i.e., with the Expert Choice software tool. One way of categorizing dry ports is based on the distance from the seaport and the function of the dry port itself. The analysis was performed for three groups of possible dry port locations (close, medium-distance and distant). According to the assessments and results obtained by the AHP methodology for selecting optimal dry port location of the Seaport Rijeka, locations are selected for each group of alternatives (close, medium distance and distant). Evaluation and justification of selected locations are also provided.

\section{Status of Seaport Rijeka in Croatian and EU Transport Network}

Croatia is located on two corridors of the basic TEN-T transport network, the Mediterranean Corridor and Rhine-Danube Corridor. The Mediterranean Corridor connects the south of the Iberian Peninsula, passes through the Spanish and French Mediterranean coasts through the Alps in northern Italy, then enters Slovenia and further towards the Hungarian-Ukrainian border. It is a road and railway corridor, and its integral part is the route Rijeka-Zagreb-Budapest (railway and road route that has become common in Croatia as PEC Vb Corridor) [12,13]. The Zagreb-Slovenia road and railway route continues to the Mediterranean Corridor, for which the name PEC X Corridor has become common in Croatia. Through this corridor, Croatia is connected in Ljubljana to the Baltic-Adriatic Corridor, which runs from the Baltic Sea through Poland, through Vienna and Bratislava to northern Italy. The Rhine-Danube Corridor is a multimodal route that connects Strasbourg, Frankfurt, Vienna, Bratislava, Budapest, from where one part forks towards Romania, and the other goes along the Danube between Croatia and Serbia and further to the Black Sea, and in Croatia it is known as PEC Corridor VII [12,14-18].

In order for the Croatian railway network to be fully integrated into the TEN-T network and become a connection of the EU TEN-T with the railway networks of the Western Balkan countries that are not yet members of the EU, it is important that the railway infrastructure meets technical standards. In addition to the interoperability that is achieved, quality railway infrastructure is a prerequisite for quality transport service.

As an integral part of the TEN-T transport network and corridors, the Seaport Rijeka is of special importance for maritime closed countries in the region (Hungary, Austria, Slovakia, the Czech Republic, Serbia and Bosnia and Herzegovina), and is in an excellent position to take advantage of its location. Seaport Rijeka is located on the strategic EU transport route (TEN-T Mediterranean Corridor) and is connected to the Baltic-Adriatic Corridor [1]. Due to its favorable position, Seaport Rijeka represents the shortest connection between Central and Central-Eastern Europe, and overseas destinations, by land and sea, and with its service is the main competitor to the ports of the northern Adriatic Sea [2].

The EU and Croatia are strategically and operationally supporting investments in port and railway infrastructure that raise the traffic capacity of this transport routes and eliminate bottlenecks in it $[2,19]$. 
Establishing a dry port serving seaport on the EU transport routes would greatly contribute to the strategic and operational plans of the EU and Croatia, which will increase the traffic capacity of the routes and eliminate bottlenecks.

Figure 1 shows the position of Seaport Rijeka in EU TEN-T and potential strategic transport directions [2].

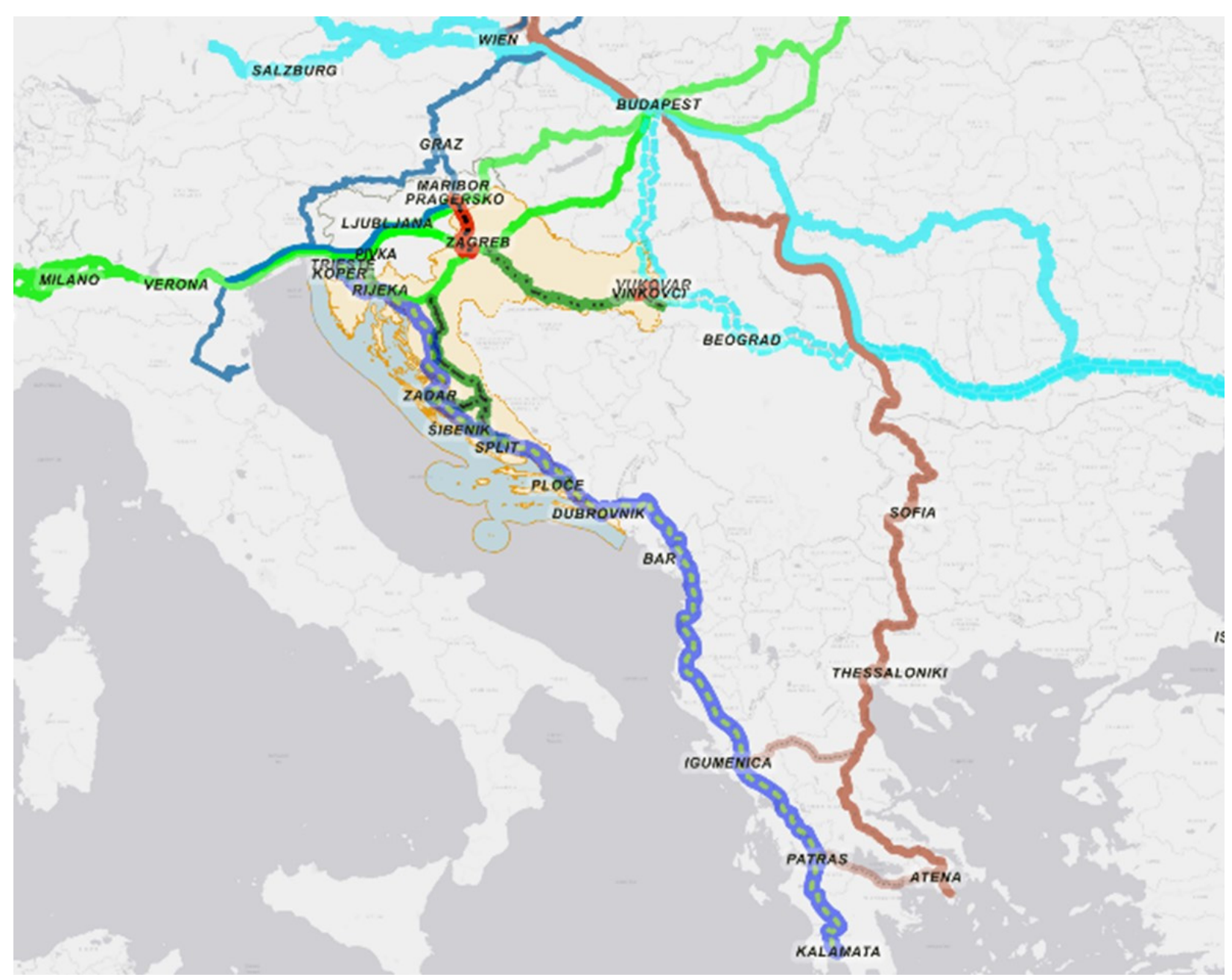

Figure 1. Position of Seaport Rijeka in TEN-T and strategic transport directions.

\section{Establishing a Dry Port as Solution to Seaport Rijeka Expansion}

Seaport Rijeka is Croatia's largest seaport. Its main activities involve transport and handling of cargo, with a focus on increasing the quality of services and the competitiveness of the transport routes in Croatia.

In the past 20 years, continuous growth in container traffic has been recorded at Seaport Rijeka $[2,20,21]$. Due to increasing demand in container traffic, Seaport Rijeka is searching for solutions to expand. One of the possible solutions that would satisfy the increasing demand in container traffic is establishing a dry port.

Dry port is an inland intermodal terminal that has direct connection to the seaport by road or rail, and its main purpose is to provide logistic activities and transport to inland destinations [22-27]. Dry ports have many advantages, faster transport of cargo from seaports, use of more efficient modes of transport, providing facilities for the storage and consolidation of goods, the maintenance of road or rail freight carriers, customs services, etc., as shown in Figure 2 [3-11]. In the case of container transport, dry ports can be used to outsource the logistic activities of transport process away from congested areas of seaports [28-35]. In addition to the many advantages brought by dry ports, dry port 
establishment also plays a large role in regional development [36]. The benefits of the introduction of one or more dry ports into freight distribution have been confirmed by several experiences in terms of logistics integration and port regionalization $[8,28-30]$.

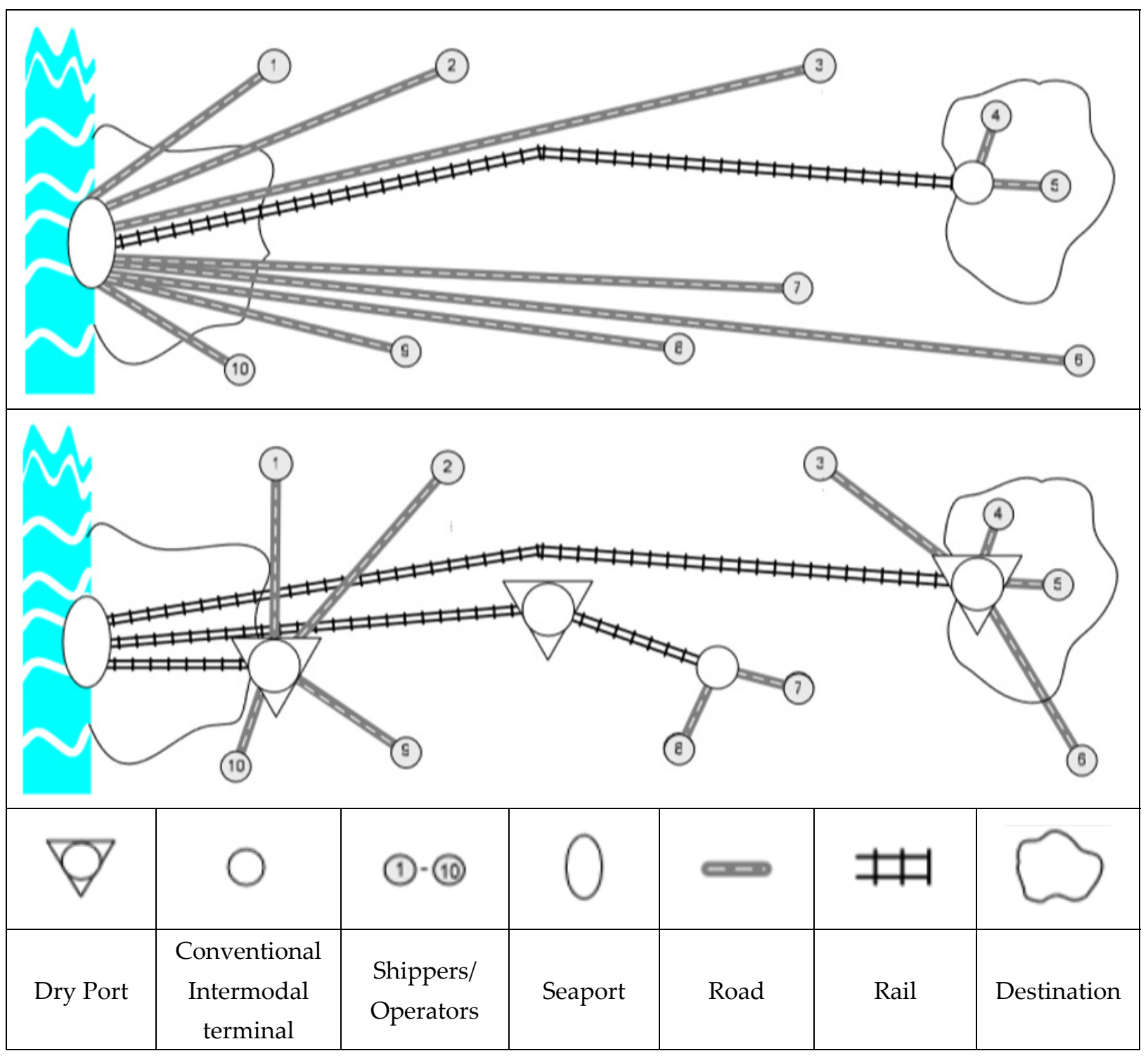

Figure 2. Comparison of conventional transport and concept with implemented dry port [30,37].

\section{Determining Influential Factors of Dry Port Establishment}

After thorough study of the literature related to factors influencing dry port establishment $[5,6,38]$, the DELPHI method [39-42] was used to determine the set of factors influencing the establishment of a new dry port, and the essential ones were obtained to determine the need for establishing a new dry port. The most important factors are seaport capacity, container traffic/future demand, technological process (time/delays/processing speed), connection with key transport corridors, i.e., the location/position of the dry port (TEN-T network), impact on the regional development, and possibility of further development of intermodal container traffic [21].

Table 1 shows the set of essential influential factors for the establishment of a new dry port. Horizontally, the factors are divided into technical, technological, organizational, ecological, information and communication (IT), economic, legal and regulatory, and 
specific. The influence of factors from the aspect of dry port location, which depends on all horizontal factors, is shown vertically.

Table 1. The set of influential factors to establish a dry port.

\begin{tabular}{|c|c|c|c|c|c|c|c|c|}
\hline \multirow{3}{*}{$\begin{array}{c}\text { LOCATION } \\
\text { ASPECT- } \\
\text { DETERMINATION } \\
\text { OF THE } \\
\text { OPTIMAL } \\
\text { LOCATION OF A } \\
\text { DRY PORT }\end{array}$} & $\begin{array}{l}\text { Technical } \\
\text { Factors }\end{array}$ & $\begin{array}{l}\text { Technological } \\
\text { Factors }\end{array}$ & $\begin{array}{c}\text { Organizational } \\
\text { Factors }\end{array}$ & $\begin{array}{l}\text { Ecological } \\
\text { Factors }\end{array}$ & IT Factors & $\begin{array}{l}\text { Economic } \\
\text { Factors }\end{array}$ & $\begin{array}{l}\text { Legal and } \\
\text { Regulatory } \\
\text { Factors }\end{array}$ & $\begin{array}{l}\text { Specific } \\
\text { Factors }\end{array}$ \\
\hline & $\begin{array}{l}\text { Dry port } \\
\text { terminal } \\
\text { infrastructure } \\
\text { (capacity and } \\
\text { condition) }\end{array}$ & $\begin{array}{l}\text { Intensity of } \\
\text { transport flows } \\
\text { and acceleration } \\
\text { of transport of } \\
\text { goods by } \\
\text { establishing a } \\
\text { dry port }\end{array}$ & $\begin{array}{l}\text { Presence and } \\
\text { cooperation of } \\
\text { dry port } \\
\text { service } \\
\text { providers } \\
\text { (operators, } \\
\text { representative } \\
\text { offices, } \\
\text { associations, } \\
\text { etc.) }\end{array}$ & $\begin{array}{l}\text { Reduction in } \\
\text { harmful emis- } \\
\text { sions/reduction } \\
\text { in air and soil } \\
\text { pollution }\end{array}$ & $\begin{array}{l}\text { Advanced } \\
\text { IT systems }\end{array}$ & $\begin{array}{c}\text { Investments in } \\
\text { the } \\
\text { construction of } \\
\text { access roads } \\
\text { and terminal } \\
\text { infrastructure }\end{array}$ & $\begin{array}{l}\text { Fitting into } \\
\text { spatial- } \\
\text { urban plans } \\
\text { and } \\
\text { complying } \\
\text { with all } \\
\text { applicable } \\
\text { regulations }\end{array}$ & $\begin{array}{c}\text { Connection } \\
\text { to the } \\
\text { TEN-T } \\
\text { network }\end{array}$ \\
\hline & $\begin{array}{c}\text { Dry port } \\
\text { transport } \\
\text { infrastructure } \\
\text { (road, rail, } \\
\text { intermodal, } \\
\text { etc.; capacity } \\
\text { and condition) }\end{array}$ & $\begin{array}{l}\text { Providing } \\
\text { additional } \\
\text { capacity and } \\
\text { relieving the } \\
\text { activities of the } \\
\text { seaport by } \\
\text { establishing a } \\
\text { dry port }\end{array}$ & $\begin{array}{l}\text { Public-private } \\
\text { or state } \\
\text { ownership } \\
\text { (dry port } \\
\text { organizational } \\
\text { structure) }\end{array}$ & $\begin{array}{l}\text { The impact of } \\
\text { the } \\
\text { environment } \\
\text { on the goods } \\
\text { in the terminal } \\
\text { and the impact } \\
\text { of the goods } \\
\text { and processes } \\
\text { in the terminal } \\
\text { on the } \\
\text { environment }\end{array}$ & $\begin{array}{l}\text { Container } \\
\text { tracking } \\
\text { systems }\end{array}$ & $\begin{array}{c}\text { Facilitating } \\
\text { international } \\
\text { trade and } \\
\text { encouraging } \\
\text { economic } \\
\text { development }\end{array}$ & $\begin{array}{l}\text { Integration } \\
\text { into the } \\
\text { railway } \\
\text { transport } \\
\text { develop- } \\
\text { ment policy } \\
\text { in the EU }\end{array}$ & $\begin{array}{l}\text { Impact on } \\
\text { regional de- } \\
\text { velopment }\end{array}$ \\
\hline
\end{tabular}

In addition to Table 1, which outlines the essential factors for the establishment of a new dry port, it must be emphasized that these are not the only ones. Table 2 shows the set of all examined influential factors to establish a dry port.

Table 2. The set of all examined influential factors to establish a dry port.

\begin{tabular}{|c|c|c|c|c|c|c|c|c|}
\hline \multirow{6}{*}{$\begin{array}{c}\text { LOCATION } \\
\text { ASPECT }\end{array}$} & $\begin{array}{l}\text { Technical } \\
\text { Factors }\end{array}$ & $\begin{array}{l}\text { Technological } \\
\text { Factors }\end{array}$ & $\begin{array}{l}\text { Organizational } \\
\text { Factors }\end{array}$ & $\begin{array}{l}\text { Ecological } \\
\text { Factors }\end{array}$ & IT Factors & $\begin{array}{l}\text { Economic } \\
\text { Factors }\end{array}$ & $\begin{array}{l}\text { Legal and } \\
\text { Regulatory } \\
\text { Factors }\end{array}$ & $\begin{array}{l}\text { Specific } \\
\text { Factors }\end{array}$ \\
\hline & $\begin{array}{l}\text { Terminal } \\
\text { infrastructure } \\
\text { (capacity and } \\
\text { condition) }\end{array}$ & $\begin{array}{l}\text { Intensity of } \\
\text { transport } \\
\text { flows }\end{array}$ & $\begin{array}{l}\text { Presence of } \\
\text { logistics } \\
\text { operators in } \\
\text { the dry port }\end{array}$ & $\begin{array}{l}\text { Reduction in } \\
\text { harmful emis- } \\
\text { sions/Reduction } \\
\text { in air and soil } \\
\text { pollution }\end{array}$ & $\begin{array}{l}\text { Advanced IT } \\
\text { systems }\end{array}$ & $\begin{array}{l}\text { Logistics costs } \\
\text { (transport, } \\
\text { storage, } \\
\text { supplies, etc.) }\end{array}$ & $\begin{array}{c}\text { Fitting into } \\
\text { spatial-urban } \\
\text { plans }\end{array}$ & $\begin{array}{l}\text { Expanding } \\
\text { to/strengthening } \\
\text { the hinterland }\end{array}$ \\
\hline & $\begin{array}{c}\text { Infrastructure } \\
\text { network } \\
\text { (electricity, } \\
\text { water, } \\
\text { drainage, etc.) }\end{array}$ & $\begin{array}{l}\text { Dry port } \\
\text { terminal } \\
\text { availability }\end{array}$ & $\begin{array}{l}\text { Logistics pol- } \\
\text { icy/government } \\
\text { support }\end{array}$ & $\begin{array}{l}\text { Noise and } \\
\text { vibration }\end{array}$ & $\begin{array}{l}\text { Container } \\
\text { tracking } \\
\text { systems }\end{array}$ & $\begin{array}{l}\text { Location } \\
\text { activation } \\
\text { costs }\end{array}$ & $\begin{array}{l}\text { Possibility of } \\
\text { ownership } \\
\text { regulation of } \\
\text { land and } \\
\text { facilities }\end{array}$ & $\begin{array}{l}\text { Connection to } \\
\text { the TEN-T } \\
\text { network }\end{array}$ \\
\hline & $\begin{array}{l}\text { Geological } \\
\text { characteristics } \\
\text { of dry port } \\
\text { terrain }\end{array}$ & $\begin{array}{l}\text { Transport time } \\
\text { of goods }\end{array}$ & $\begin{array}{c}\text { Presence of } \\
\text { intermodal } \\
\text { transport } \\
\text { operators }\end{array}$ & $\begin{array}{c}\text { Hazardous } \\
\text { materials }\end{array}$ & & $\begin{array}{l}\text { Investments in } \\
\text { the } \\
\text { construction of } \\
\text { access roads } \\
\text { and } \\
\text { infrastructure }\end{array}$ & $\begin{array}{l}\text { Simplification of } \\
\text { institutional and } \\
\text { regulatory } \\
\text { frameworks }\end{array}$ & $\begin{array}{l}\text { Connection to } \\
\text { the other } \\
\text { relevant } \\
\text { hubs/terminals }\end{array}$ \\
\hline & $\begin{array}{l}\text { Rail transport } \\
\text { infrastructure }\end{array}$ & $\begin{array}{l}\text { Connection } \\
\text { with several } \\
\text { modes of } \\
\text { transport }\end{array}$ & $\begin{array}{l}\text { Possibility of } \\
\text { organizing } \\
\text { line } \\
\text { connections in } \\
\text { railway } \\
\text { transport }\end{array}$ & $\begin{array}{l}\text { Dangerous } \\
\text { goods }\end{array}$ & & $\begin{array}{l}\text { Net present } \\
\text { value }\end{array}$ & $\begin{array}{l}\text { Regulations } \\
\text { related to the } \\
\text { handling of } \\
\text { goods } \\
\text { (dangerous } \\
\text { goods) and } \\
\text { terminal } \\
\text { equipment }\end{array}$ & $\begin{array}{l}\text { Impact on } \\
\text { regional } \\
\text { development }\end{array}$ \\
\hline & $\begin{array}{c}\text { Infrastructure } \\
\text { for } \\
\text { double-deck } \\
\text { trains }\end{array}$ & $\begin{array}{l}\text { Availability of } \\
\text { intermodal } \\
\text { transport } \\
\text { terminals }\end{array}$ & $\begin{array}{l}\text { Cooperation } \\
\text { of participants } \\
\text { in the } \\
\text { transport } \\
\text { system } \\
\text { (representative } \\
\text { offices, } \\
\text { associations, } \\
\text { companies in } \\
\text { the field of } \\
\text { transport and } \\
\text { logistics, etc.) }\end{array}$ & $\begin{array}{l}\text { Influence of } \\
\text { the } \\
\text { environment } \\
\text { on the goods } \\
\text { in the terminal }\end{array}$ & & Refund period & $\begin{array}{l}\text { Compliance with } \\
\text { laws governing } \\
\text { the presence, } \\
\text { distance and } \\
\text { protection of the } \\
\text { terminal } \\
\text { environment, } \\
\text { control and } \\
\text { status of goods } \\
\text { in the terminal }\end{array}$ & \\
\hline
\end{tabular}


Table 2. Cont.

\begin{tabular}{|c|c|c|c|c|c|c|c|c|}
\hline & $\begin{array}{l}\text { Technical } \\
\text { Factors }\end{array}$ & $\begin{array}{l}\text { Technological } \\
\text { Factors }\end{array}$ & $\begin{array}{l}\text { Organizational } \\
\text { Factors }\end{array}$ & $\begin{array}{l}\text { Ecological } \\
\text { Factors }\end{array}$ & IT Factors & $\begin{array}{l}\text { Economic } \\
\text { Factors }\end{array}$ & $\begin{array}{l}\text { Legal and } \\
\text { Regulatory } \\
\text { Factors }\end{array}$ & $\begin{array}{l}\text { Specific } \\
\text { Factors }\end{array}$ \\
\hline & $\begin{array}{c}\text { Road } \\
\text { transport } \\
\text { infrastructure }\end{array}$ & $\begin{array}{l}\text { Ensuring } \\
\text { additional } \\
\text { seaport } \\
\text { capacity }\end{array}$ & $\begin{array}{l}\text { Agreements } \\
\text { on operational } \\
\text { agreements }\end{array}$ & $\begin{array}{l}\text { The impact of } \\
\text { goods and } \\
\text { processes in } \\
\text { the terminal } \\
\text { on the } \\
\text { environment }\end{array}$ & & $\begin{array}{c}\text { Impact on } \\
\text { market } \\
\text { development }\end{array}$ & $\begin{array}{l}\text { Fitting into the } \\
\text { railway } \\
\text { transport } \\
\text { development } \\
\text { policy in the EU }\end{array}$ & \\
\hline & $\begin{array}{l}\text { Intermodal } \\
\text { infrastructure }\end{array}$ & $\begin{array}{l}\text { Relieving } \\
\text { seaport } \\
\text { activities }\end{array}$ & $\begin{array}{l}\text { Public-private } \\
\text { or state } \\
\text { property }\end{array}$ & & & $\begin{array}{l}\text { Facilitating } \\
\text { international } \\
\text { trade }\end{array}$ & & \\
\hline & $\begin{array}{l}\text { Required } \\
\text { manpower }\end{array}$ & $\begin{array}{c}\text { Development } \\
\text { of } \\
\text { value-added } \\
\text { services }\end{array}$ & $\begin{array}{l}\text { Coordination } \\
\text { between } \\
\text { different } \\
\text { government } \\
\text { agencies }\end{array}$ & & & $\begin{array}{l}\text { Encouraging } \\
\text { economic } \\
\text { development }\end{array}$ & & \\
\hline \multirow[t]{4}{*}{$\begin{array}{l}\text { LOCATION } \\
\text { ASPECT }\end{array}$} & & & $\begin{array}{c}\text { Better } \\
\text { utilization of } \\
\text { regional } \\
\text { transport } \\
\text { infrastructure }\end{array}$ & & & $\begin{array}{c}\text { Lower } \\
\text { distribution } \\
\text { cost }\end{array}$ & & \\
\hline & & & & & & $\begin{array}{l}\text { Lower land } \\
\text { costs and taxes }\end{array}$ & & \\
\hline & & & & & & $\begin{array}{l}\text { Marketing } \\
\text { support of } \\
\text { local economic } \\
\text { agencies and } \\
\text { the state }\end{array}$ & & \\
\hline & & & & & & $\begin{array}{l}\text { Gravity of } \\
\text { developed } \\
\text { economy }\end{array}$ & & \\
\hline
\end{tabular}

\section{AHP Decision-Making Methodology to Determine the Optimal Dry Port Location for Seaport Rijeka}

Among the methods of multi-criteria decision-making, AHP (Analytical Hierarchy Process) occupies a special place. The AHP methodology has great importance in structuring the problem and decision-making process. It is one of the well-known and most widely used methods for multi-criteria decision making. This method was developed in 1971 by Thomas L. Saaty [43-47]. By applying the AHP, it is possible to interactively create the hierarchy of the problem that serves as the preparation for decision-making, then compare the criteria and alternate pairs, and finally synthesize all the comparisons and determine the weight coefficients of all the hierarchy elements. The sum of the weight coefficients of the elements at each hierarchy level is equal to 1 and allows the decision maker to rank all hierarchy elements by importance [21,48-50]. Its popularity is based on the decision-making approach that is used to intuitively break problem down into simpler aspects. It also contains a mathematical model that allows a more detailed analysis of the problem [51]. Solving complex problems is based on breaking it down into components: goal, criteria, and alternatives. The criteria can be broken down into sub-criteria, and alternatives are found at the lowest level.

The AHP multi-criteria decision-making process was used to determine priorities among influential factors, and to estimate the optimal dry port location due to these factors (Table 1). The analysis was conducted using the Expert Choice software tool. Before conducting the analysis, the survey was conducted in the way that each expert graded (in his/her own opinion) the factors and alternatives with the scale from 1 to 9 . The group of experts consists of 10 experts in the field of maritime transport, intermodal transport and transport and traffic technology. Surveys were conducted anonymously, and, upon receiving results of survey, they were inserted in the Expert Choice software to conduct the analysis. The results of the analysis were obtained according to the survey results.

The AHP methodology was used to determine the optimal dry port location of the Seaport Rijeka, i.e., the Expert Choice software tool. The hierarchical AHP decision-making model for 
ranking possible alternatives of selecting dry port location is shown in Figure 3. Eight groups of factors and criteria were defined, and two sub-criteria were defined in each group of criteria, as per Section 4, Table 1.

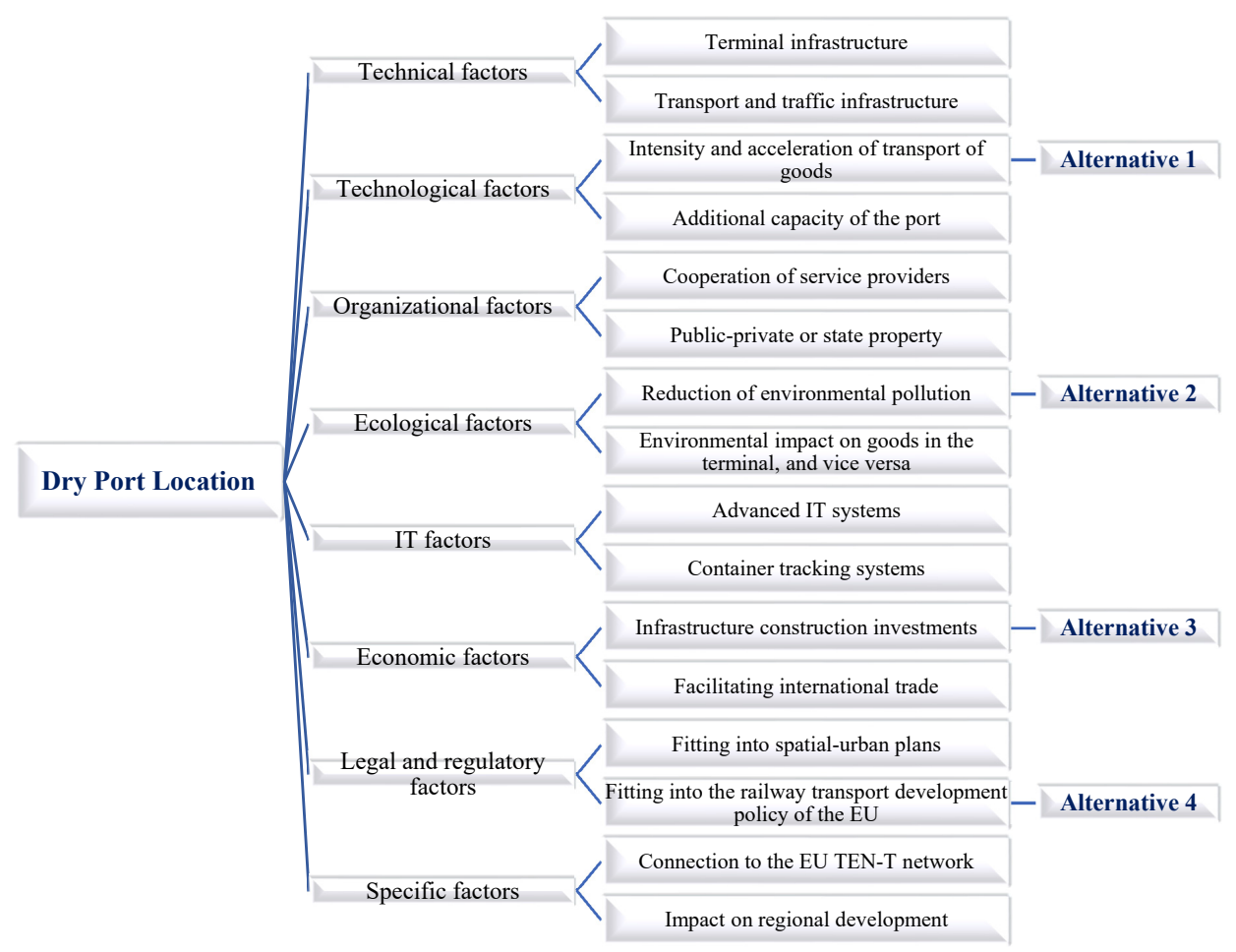

Figure 3. Hierarchical AHP decision-making model with associated criteria and sub-criteria in determining the optimal dry port location.

One way of categorizing dry ports is based on the distance from the seaport and the function of the dry port itself. There are three categories: close, medium-distance, and distant dry ports $[30,52,53]$. The analysis was performed for three groups of possible dry port locations (close, medium distance and distant).

The three groups of possible dry port locations for Seaport Rijeka include the following alternatives for each group:

1. For selection of close dry port location, alternatives are Miklavlje, Škrljevo, Lokve and Delnice;

2. For selection of medium-distance dry port location, alternatives are Zagreb-RTZ, Velika Gorica, Dugo Selo, Ivanić Grad;

3. For selection of distant dry port location, alternatives are Slavonski Brod, Osijek, Vinkovci, Vukovar.

The following Figures 4-9 show the hierarchical AHP decision-making model with associated criteria, sub-criteria, and alternatives for determining the optimal location of close, medium-distance and distant dry port, with accompanying illustrations of geographical positions. 


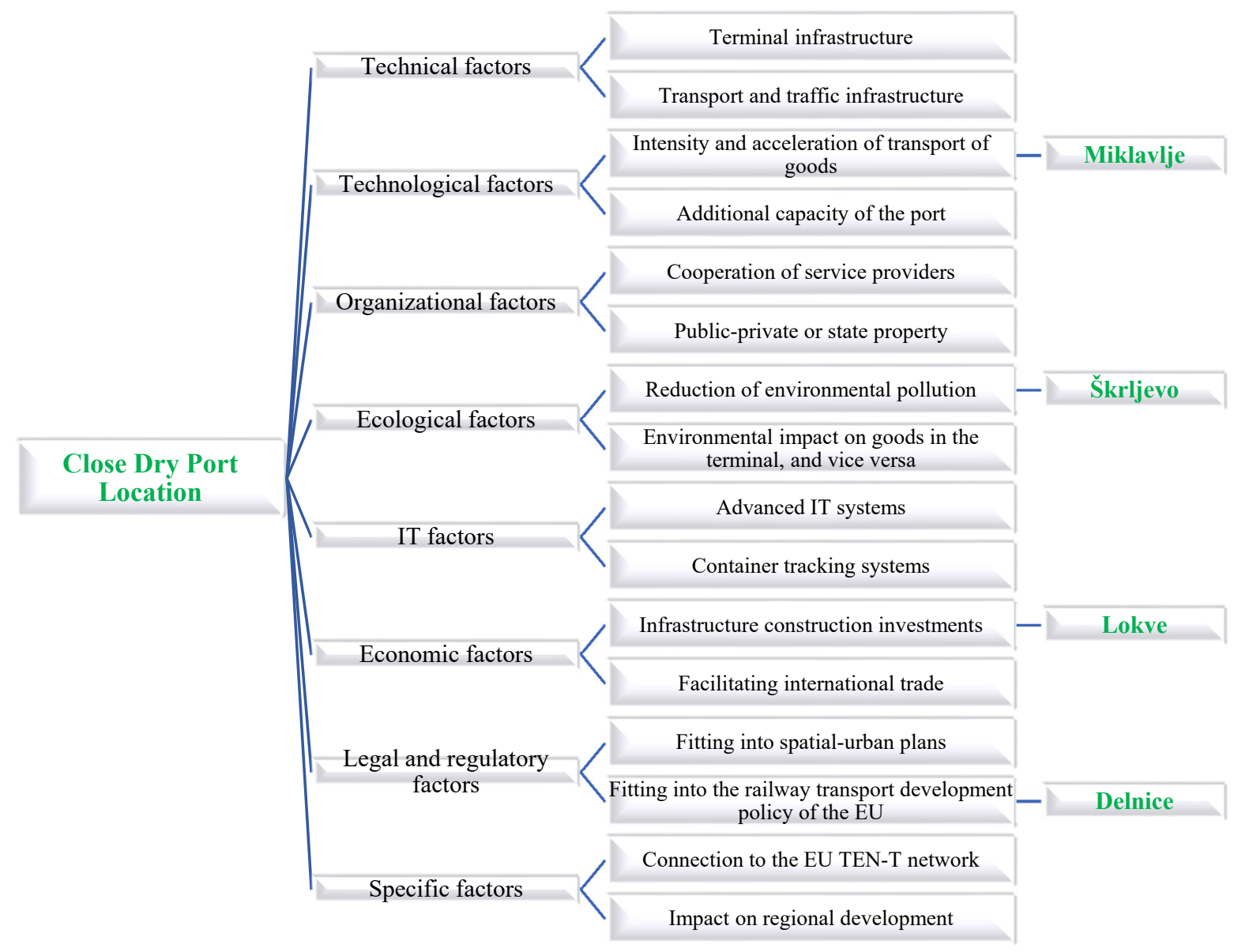

Figure 4. Hierarchical AHP decision-making model with associated criteria, sub-criteria, and alternatives for determining the optimal location of close dry port.

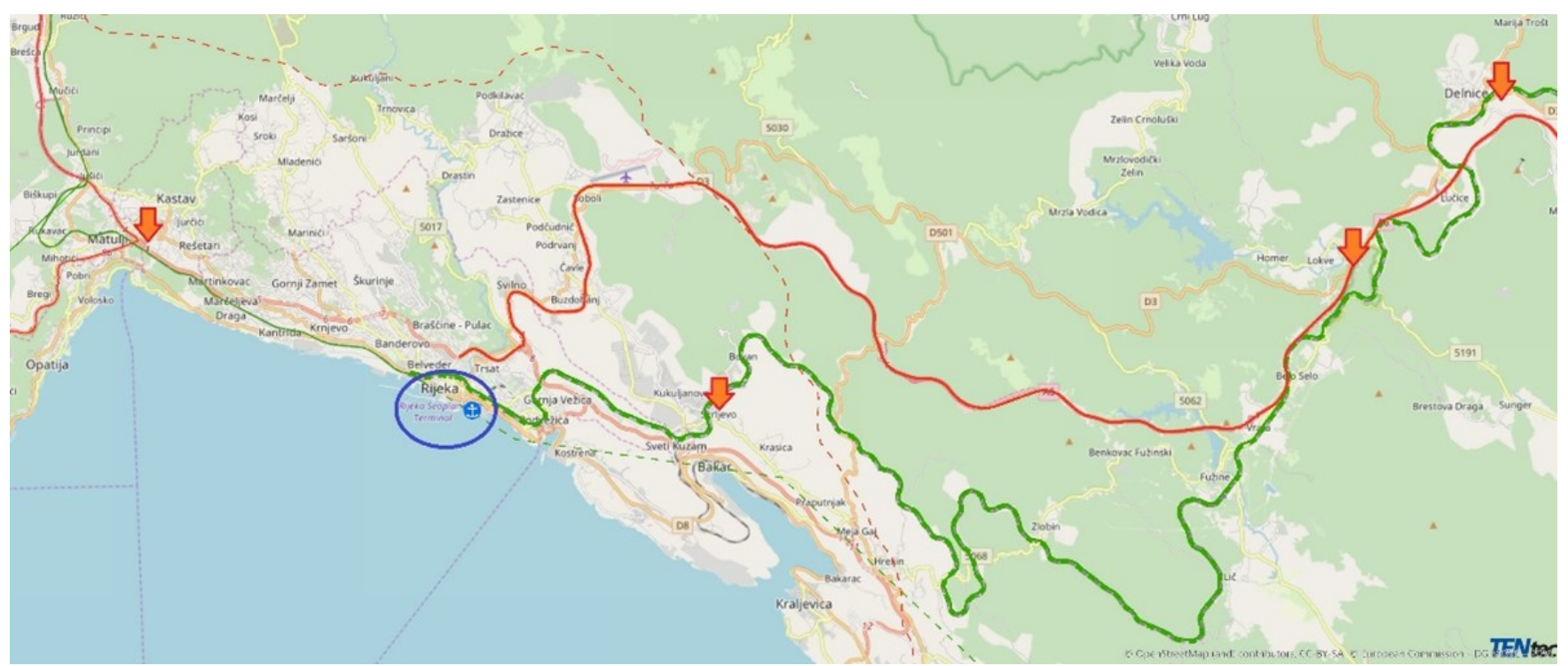

Figure 5. Geographic locations of close dry port alternatives for Seaport Rijeka in the TEN-T network. 


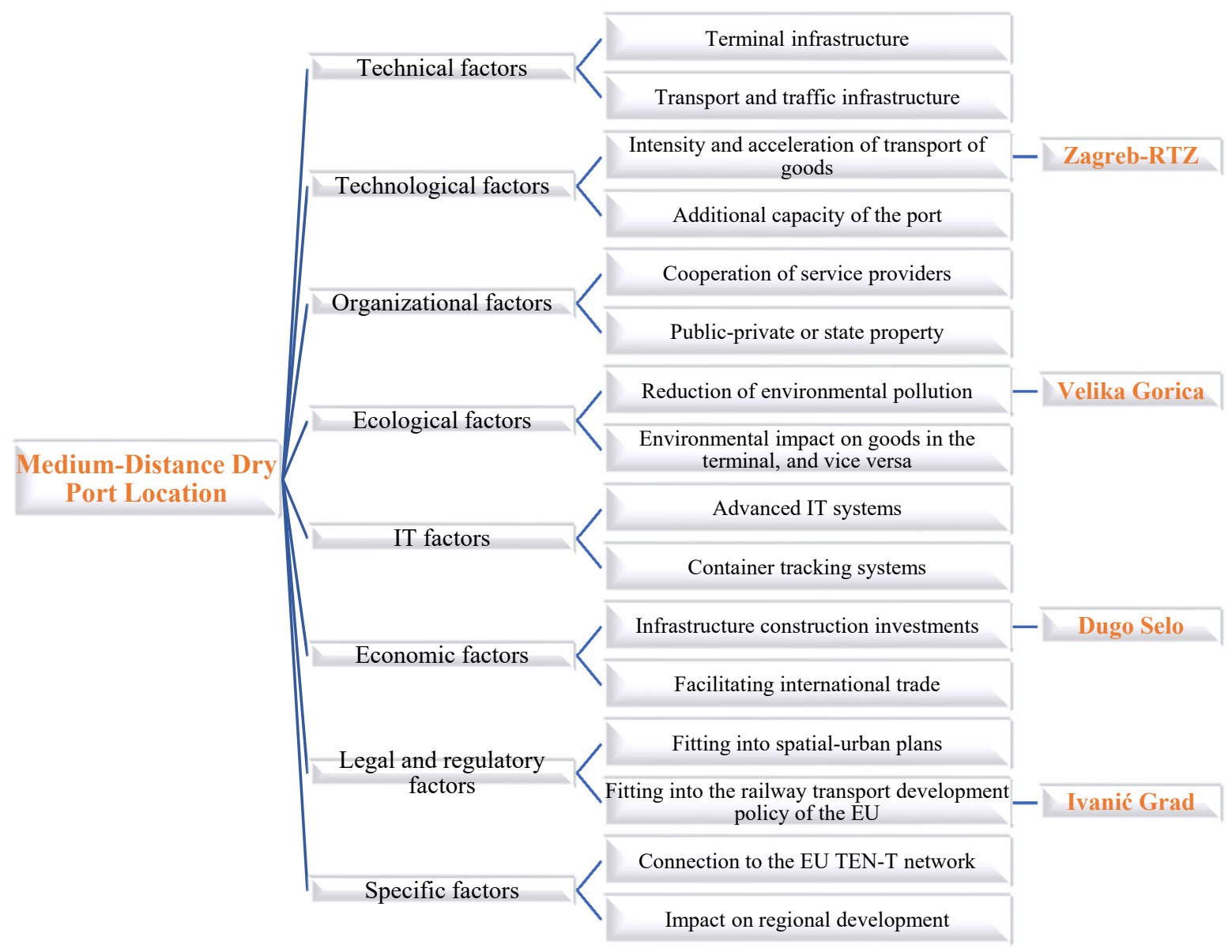

Figure 6. Hierarchical AHP decision-making model with associated criteria, sub-criteria, and alternatives for determining the optimal location of medium-distance dry port.

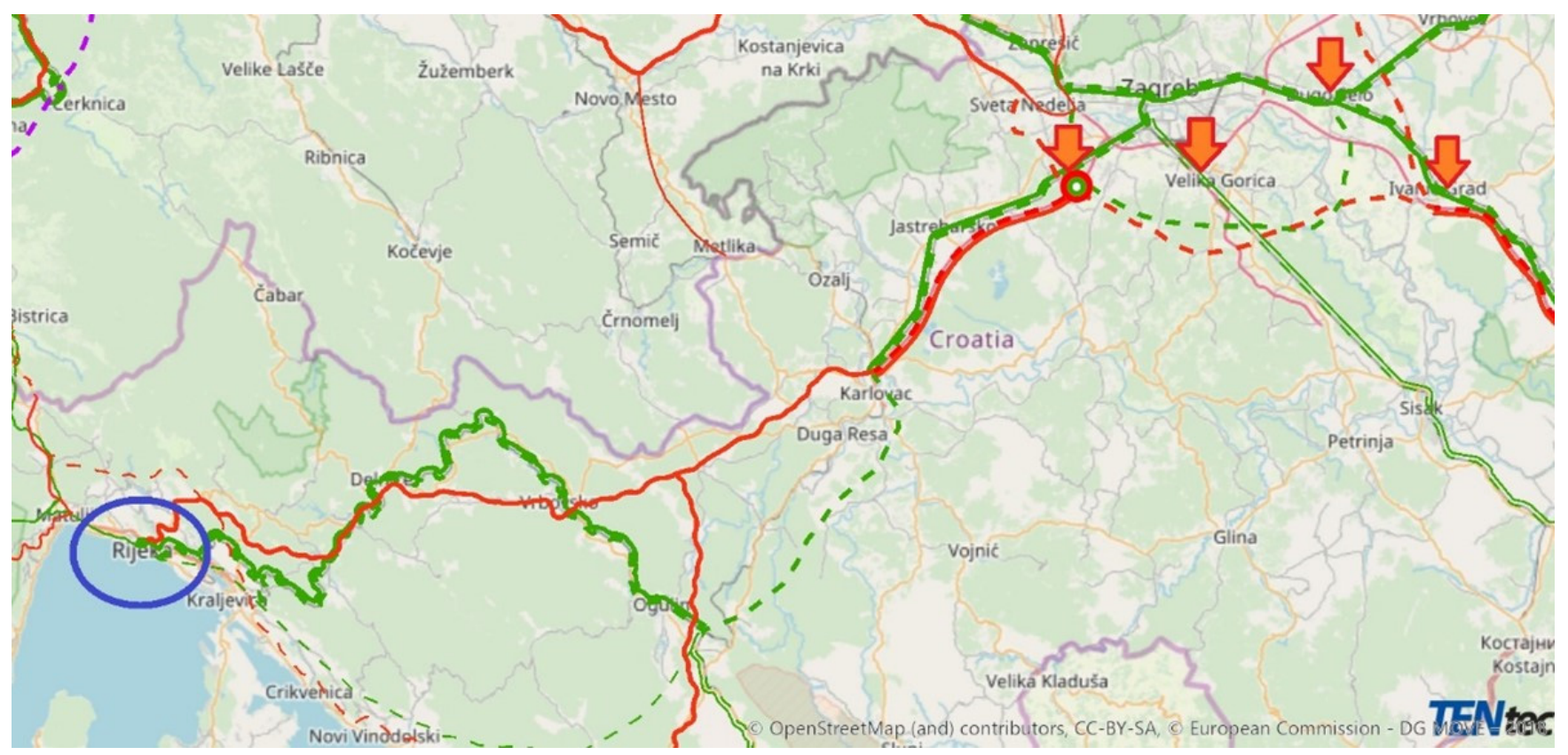

Figure 7. Geographic locations of medium-distance dry port alternatives for Seaport Rijeka in the TEN-T network. 


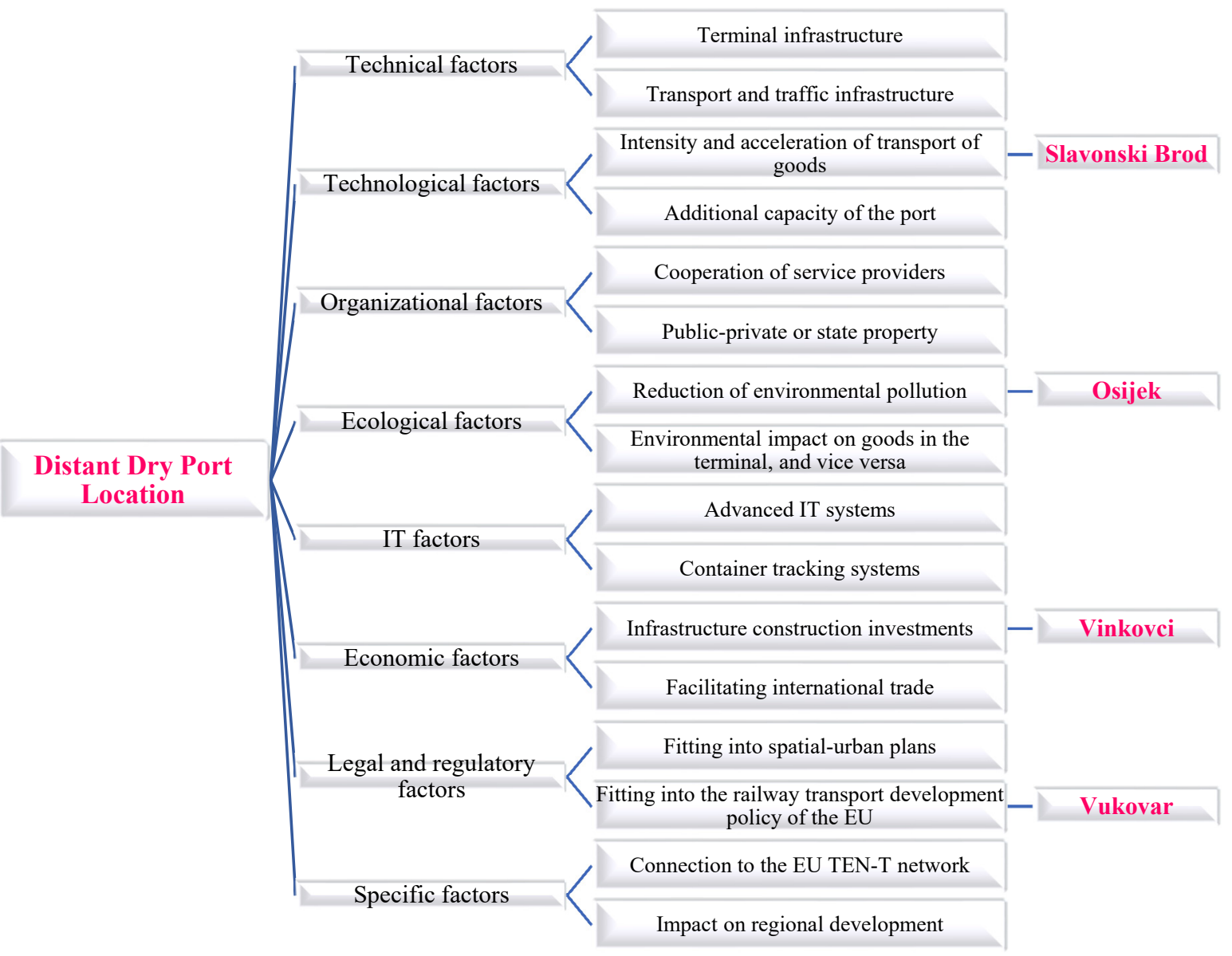

Figure 8. Hierarchical AHP decision-making model with associated criteria, sub-criteria, and alternatives for determining the optimal location of distant dry port.

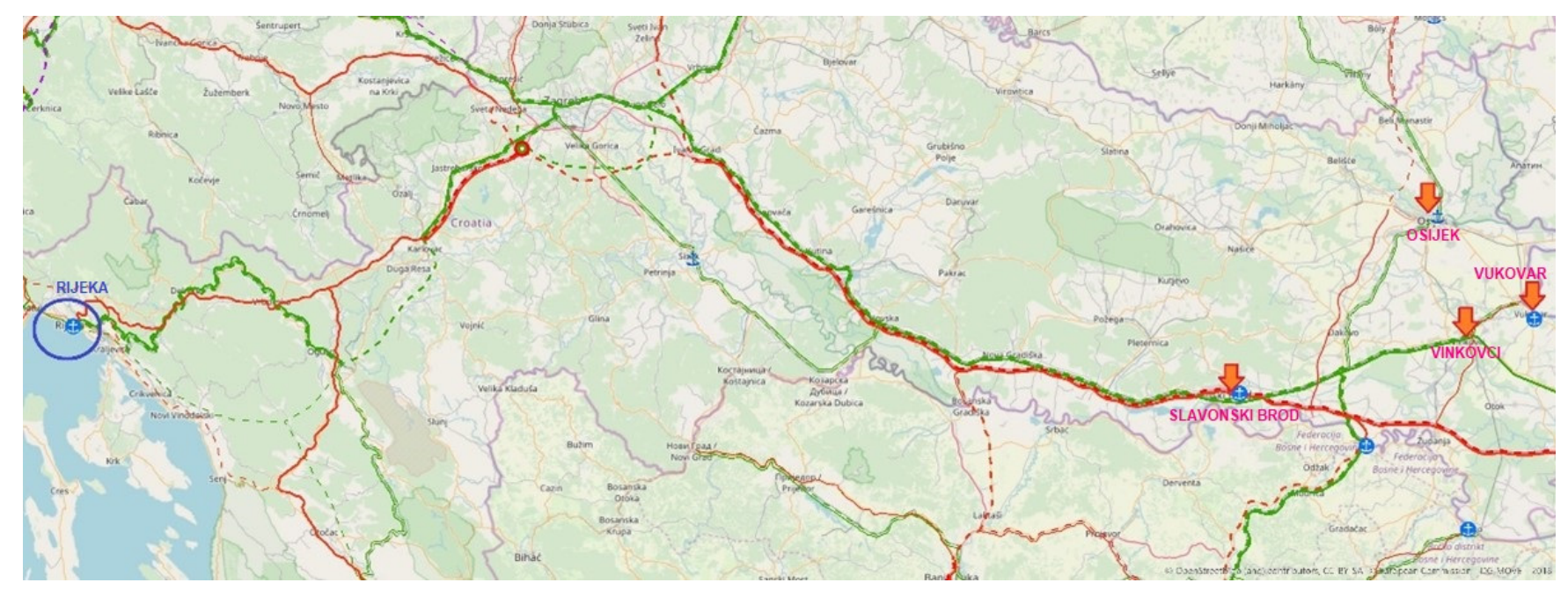

Figure 9. Geographic locations of distant dry port alternatives for Seaport Rijeka in the TEN-T network.

\section{Results}

The Expert Choice software tool was used to evaluate the possible alternatives and determine the optimal dry port location in each observation group (close, medium-distance, and distant dry port). 
Criteria with sub-criteria presented in Section 5 were evaluated by the expert assessment of the research participants using the Saaty scale, in accordance with the AHP methodology. After that, a synthesis of individual priorities was made into a group assessment of alternatives, i.e., possible locations. The evaluated and ranked alternatives were also evaluated according to all criteria and sub-criteria.

When comparing the criteria for determining the location of a close dry port, which referred to eight criteria groups, and according to individual assessments of participants, which are aggregated into the group assessment, the most important criteria are specific factors (0.171). This is followed by economic factors (0.162), ecological factors (0.151), organizational factors (0.113), legal and regulatory factors (0.111), technological factors $(0.106)$, and IT factors (0.094). The least important were the technical factors (0.092) (Figure 10).

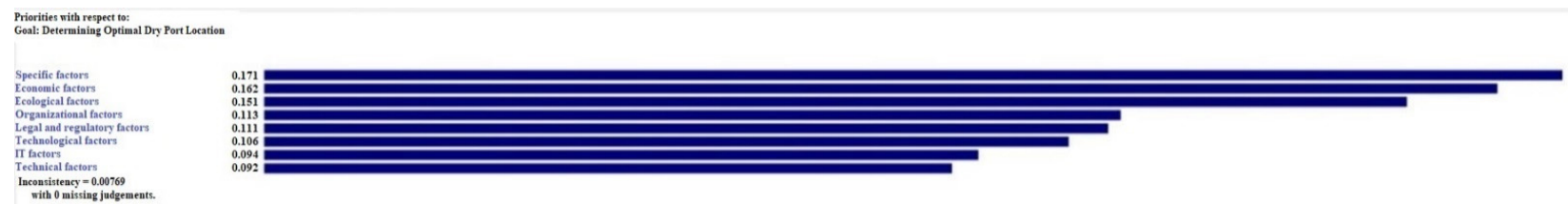

Figure 10. Comparison of criteria for determining the location of a close dry port of the Seaport Rijeka.

When comparing the criteria for determining the location of a medium-distance dry port, which referred to eight criteria groups, and according to individual assessments of participants, which are aggregated into the group assessment, the most important criteria are specific factors (0.278). This is followed by ecological factors (0.197), economic factors (0.180), legal-regulatory factors $(0.100)$, organizational factors $(0.090)$, technological factors $(0.061)$, and IT factors $(0.055)$. The least important were the technical factors (0.039) (Figure 11).

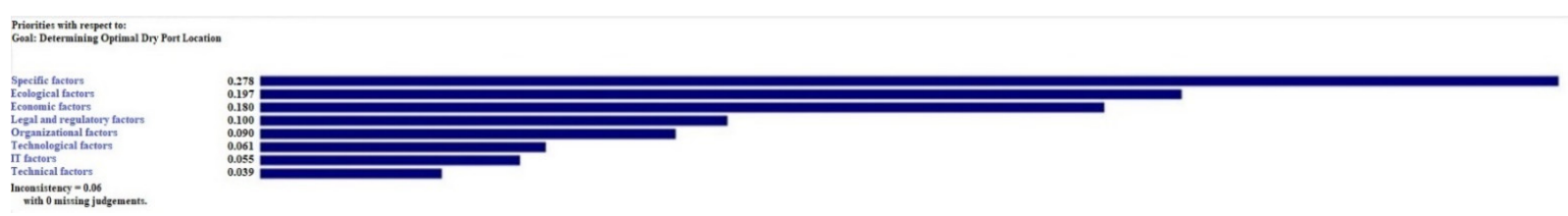

Figure 11. Comparison of criteria for determining the location of a medium-distance dry port of the Seaport Rijeka.

When comparing the criteria for determining the location of a distant dry port, which referred to eight criteria groups, and according to individual assessments of participants, which are aggregated into a group assessment, the most important criteria are specific factors $(0.281)$. Then, there are economic factors (0.209), ecological factors (0.164), legalregulatory factors (0.094), organizational factors $(0.085)$, IT factors $(0.065)$, and technological factors (0.058). The least important were the technical factors (0.045) (Figure 12).
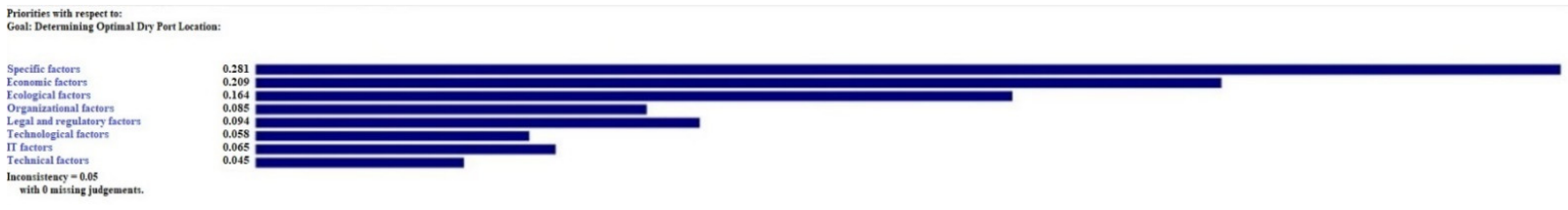

Figure 12. Comparison of criteria for determining the location of a distant dry port of the Seaport Rijeka.

\subsection{Optimal Close Dry Port Location for Seaport Rijeka}

Quantitative factors were classified using the Expert Choice software tool ranking the alternatives directly according to the calculated values. In evaluating all groups of factors, participants used a scale in values from 1 to 9 to evaluate interrelated factors, which include two sub-criteria in each group. According to the assessment of the importance or influence of factors (Figure 13), the most acceptable alternative for the close dry port of the Seaport 
Rijeka is Miklavlje with a priority of 0.578 . It is followed by Škrljevo with 0.218 , Lokve with 0.109 and Delnice with 0.096 .

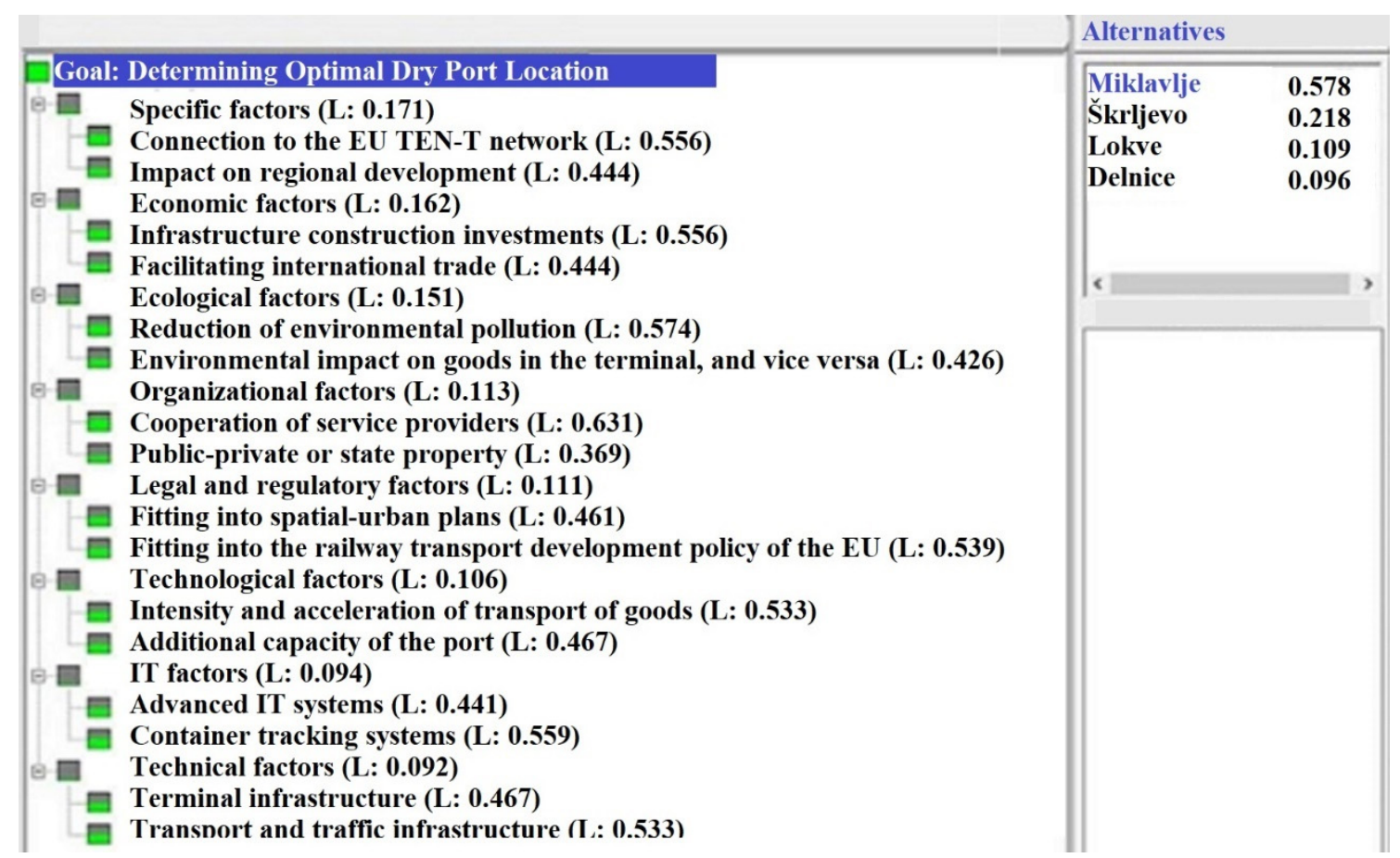

Figure 13. Presentation of all groups of influencing factors (criteria) and results of the overall assessment in determining the optimal location of a close dry port for Seaport Rijeka.

In order to investigate the existing order of ranked alternatives when changing the weights of individual criteria, a sensitivity analysis was performed. The computer function, Performance, of the Expert Choice program was used. Figure 14 shows the sensitivity analysis of the close dry port alternatives, using the Performance option. Miklavlje makes a very strong case for being the best alternative; oscillation is possible between alternatives, Lokve and Delnice.

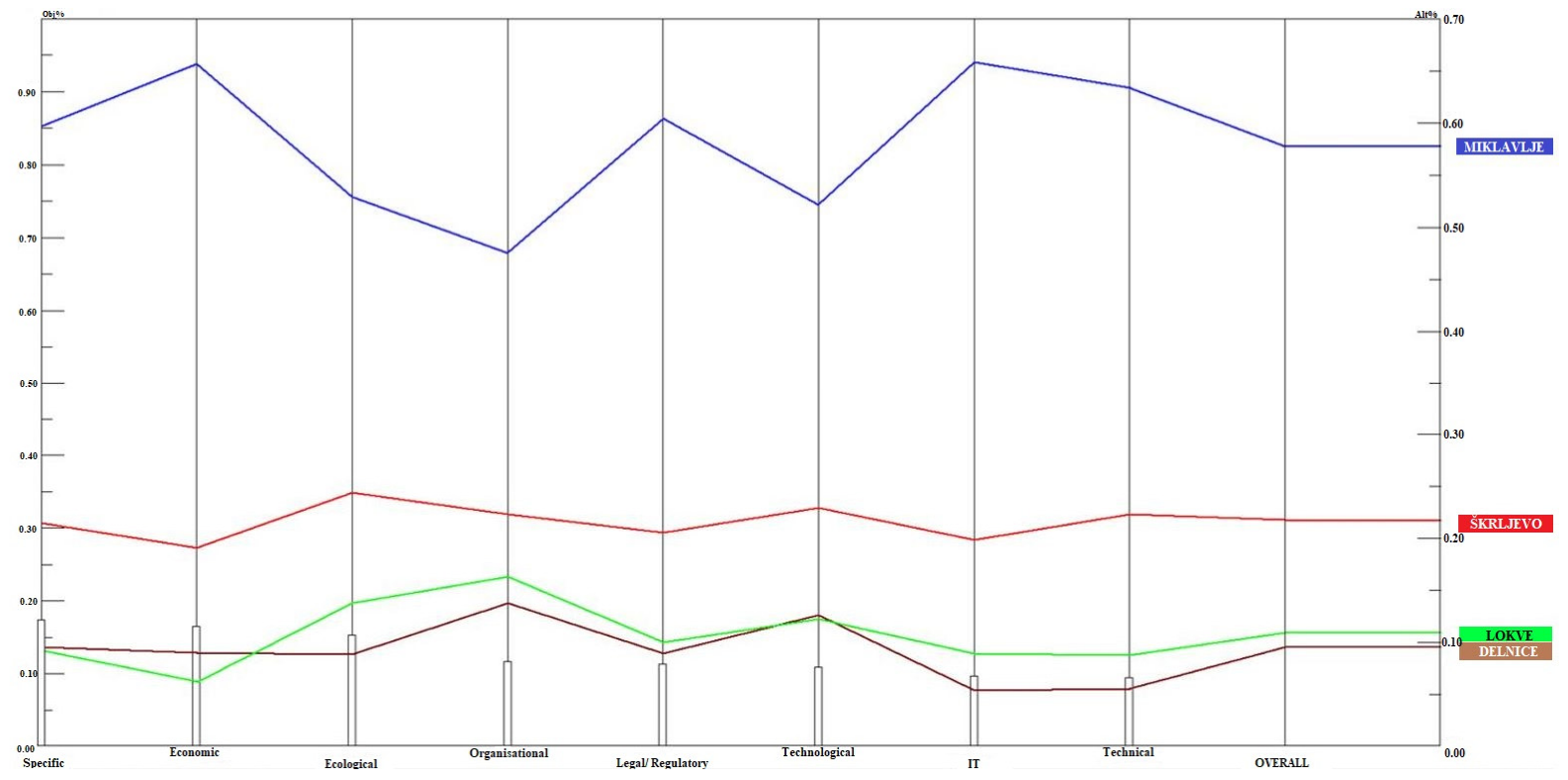

Figure 14. Sensitivity analysis of close dry port location selection criteria using the Performance option. 


\subsection{Optimal Medium-Distance Dry Port Location for Seaport Rijeka}

Quantitative factors were classified using the Expert Choice software tool ranking the alternatives directly according to the calculated values. In evaluating all groups of factors, participants used a scale in values from 1 to 9 to evaluate interrelated factors, which include two sub-criteria in each group. According to the assessment of the importance or influence of factors (Figure 15), the most acceptable alternative for the medium-distance dry port of the Seaport Rijeka is Velika Gorica with a priority of 0.271. It is followed by Zagreb-RTZ with 0.246, Dugo Selo with 0.245 and Ivanić Grad with 0.238.

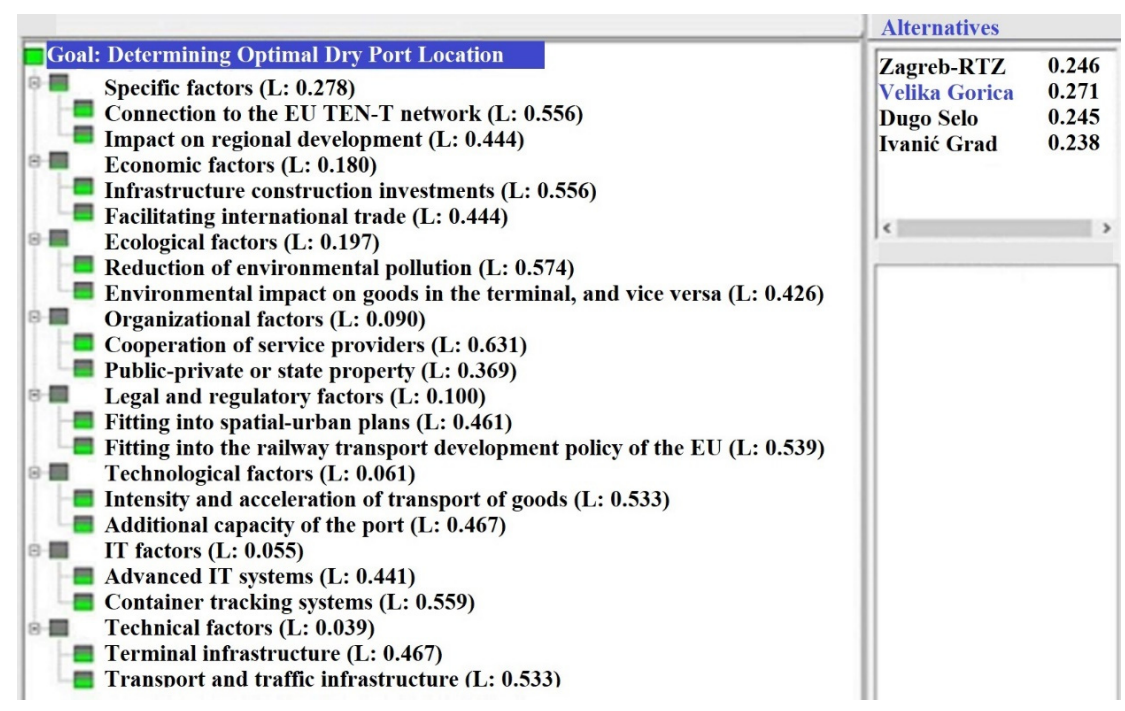

Figure 15. Presentation of all groups of influencing factors (criteria) and results of the overall assessment in determining the optimal location of a medium-distance dry port for Seaport Rijeka.

In order to investigate the existing order of ranked alternatives when changing the weights of individual criteria, a sensitivity analysis was performed. The computer function, Performance, of the Expert Choice program was used. Figure 16 shows the sensitivity analysis of mediumdistance dry port alternatives, using the Performance option. It can be observed that alternatives are ranked by very small difference, and Velika Gorica is shown to be the best alternative by little in comparison to other alternatives. Further analysis of these alternatives might be necessary in order to determine which one is truly optimal, but, for the sake of this study, Velika Gorica can be accepted as the best alternative.

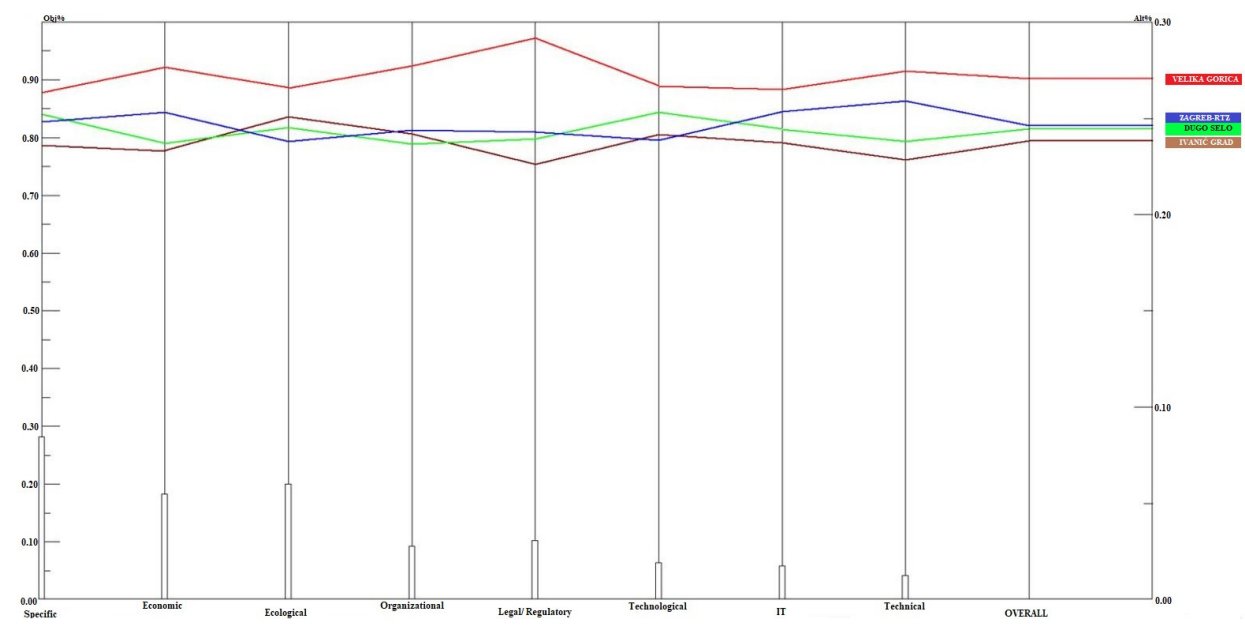

Figure 16. Sensitivity analysis of medium-distance dry port location selection criteria using the Performance option. 


\subsection{Optimal Distant Dry Port Location for Seaport Rijeka}

Quantitative factors were classified using the Expert Choice software tool ranking the alternatives directly according to the calculated values. In evaluating all groups of factors, participants used a scale in values from 1 to 9 to evaluate interrelated factors, which include two sub-criteria in each group. According to the assessment of the importance or influence of factors (Figure 17), the most acceptable alternative for the distant dry port of the Seaport Rijeka is Vinkovci with a priority of 0.299. It is followed by Vukovar with 0.255, Slavonski Brod with 0.227 and Osijek with 0.218 .

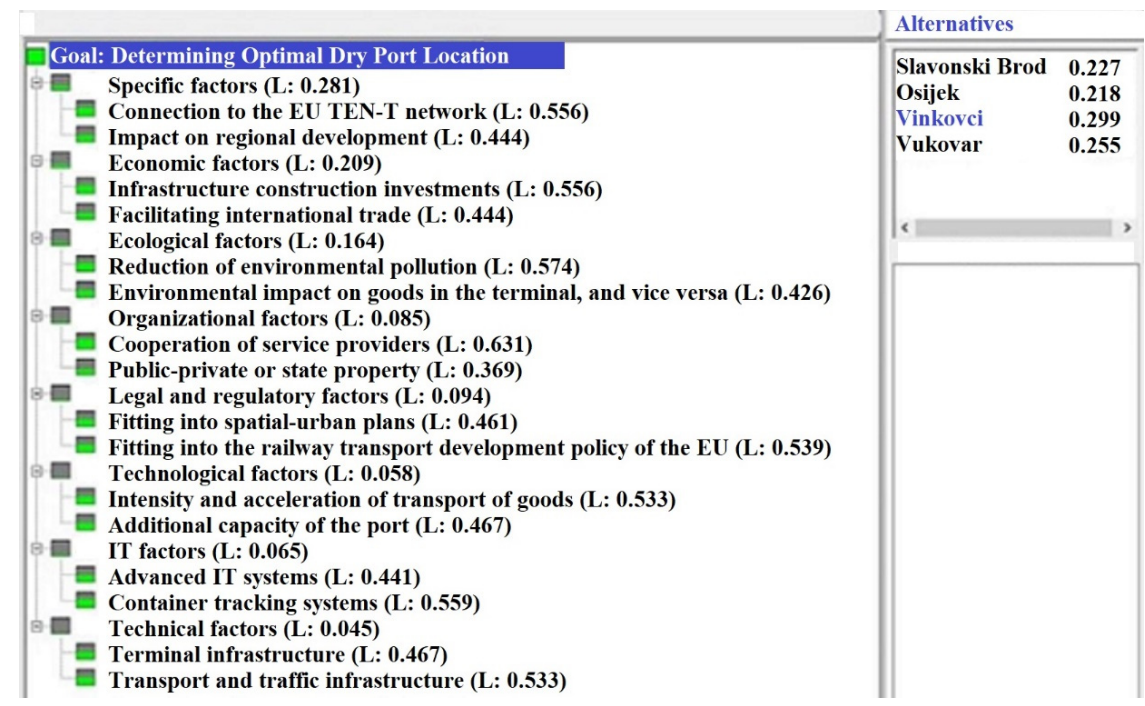

Figure 17. Presentation of all groups of influencing factors (criteria) and results of the overall assessment in determining the optimal location of a distant dry port for Seaport Rijeka.

In order to investigate the existing order of ranked alternatives when changing the weights of individual criteria, a sensitivity analysis was performed. The computer function, Performance, of the Expert Choice program was used. Figure 18 shows the sensitivity analysis of distant dry port alternatives, using the Performance option. City of Vinkovci makes a fair case for being the best alternative; oscillation is possible between the other three alternatives.

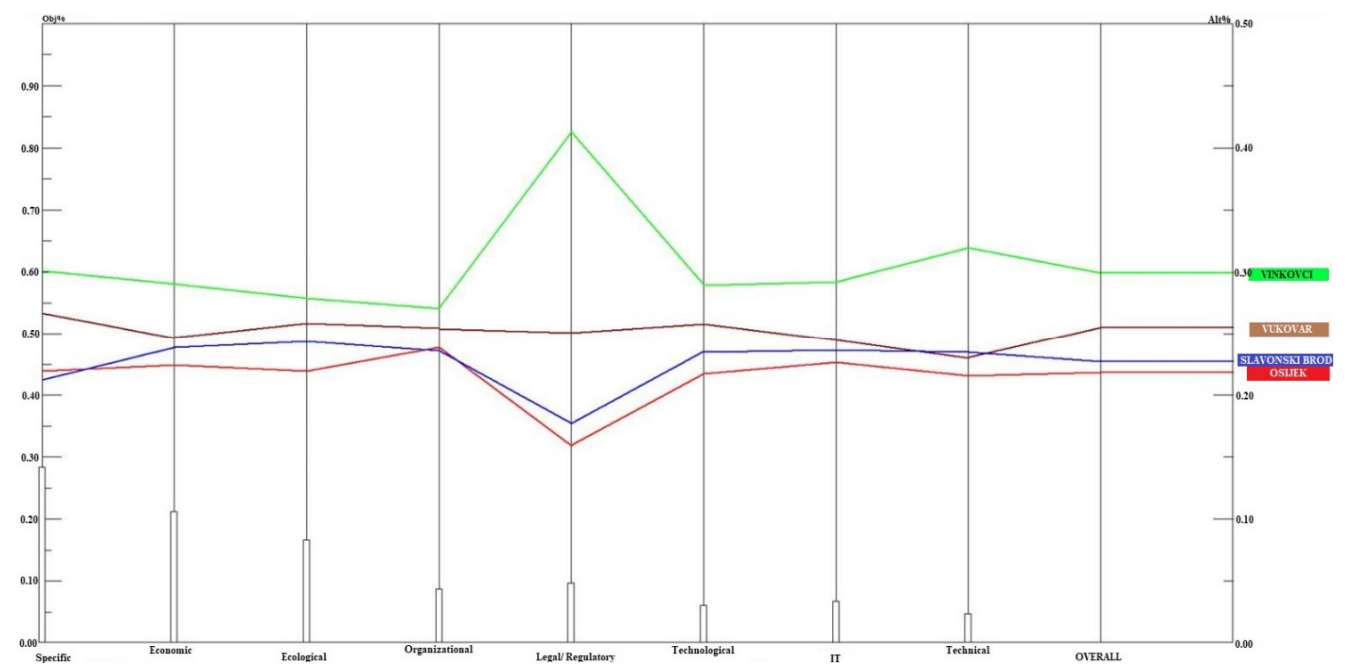

Figure 18. Sensitivity analysis of distant dry port location selection criteria using the Performance option.

Table 3 shows all results of the analysis conducted using Expert Choice software tool, for each chosen alternative. 
Table 3. The results of selecting the optimal dry port location of the Seaport Rijeka using the AHP methodology and the software tool, Expert Choice.

\begin{tabular}{|c|c|c|c|c|c|c|c|c|c|c|c|c|c|c|c|}
\hline \multirow{3}{*}{ No. } & \multirow{3}{*}{ Category } & \multirow{3}{*}{ No. } & \multirow{3}{*}{ Factors } & \multicolumn{12}{|c|}{ DRY PORT LOCATION ALTERNATIVES } \\
\hline & & & & \multicolumn{4}{|c|}{$\begin{array}{c}\text { Close Dry Port Location } \\
\text { Alternatives }\end{array}$} & \multicolumn{4}{|c|}{$\begin{array}{l}\text { Mid-Range Dry Port Location } \\
\text { Alternatives }\end{array}$} & \multicolumn{4}{|c|}{$\begin{array}{l}\text { Distant Dry Port Location } \\
\text { Alternatives }\end{array}$} \\
\hline & & & & Miklavlje & Škrljevo & Lokve & Delnice & $\begin{array}{l}\text { Zagreb- } \\
\text { RTZ }\end{array}$ & $\begin{array}{l}\text { Velika } \\
\text { Gorica }\end{array}$ & Dugo Selo & $\begin{array}{c}\text { Ivanić } \\
\text { Grad }\end{array}$ & $\begin{array}{l}\text { Slavonski } \\
\text { Brod }\end{array}$ & Osijek & Vinkovci & Vukovar \\
\hline \multirow{2}{*}[1]{} & \multirow{2}{*}{$\begin{array}{l}\text { Technical } \\
\text { factors }\end{array}$} & [1] & Terminal infrastructure & 0.675 & 0.192 & 0.087 & 0.046 & 0.270 & 0.271 & 0.238 & 0.222 & 0.229 & 0.229 & 0.312 & 0.230 \\
\hline & & [2] T & Transport and traffic infrastructure & 0.601 & 0.247 & 0.089 & 0.063 & 0.250 & 0.279 & 0.238 & 0.234 & 0.240 & 0.204 & 0.326 & 0.230 \\
\hline & \multirow{2}{*}{$\begin{array}{l}\text { Technological } \\
\text { factors }\end{array}$} & [3] & $\begin{array}{l}\text { Intensity and acceleration of } \\
\text { transport of goods }\end{array}$ & 0.514 & 0.223 & 0.149 & 0.114 & 0.239 & 0.265 & 0.253 & 0.243 & 0.226 & 0.215 & 0.298 & 0.260 \\
\hline & & [4] & Additional capacity of the port & 0.531 & 0.237 & 0.091 & 0.141 & 0.238 & 0.269 & 0.253 & 0.239 & 0.245 & 0.219 & 0.280 & 0.256 \\
\hline \multirow{2}{*}{ [3] } & \multirow{2}{*}{$\begin{array}{l}\text { Organizational } \\
\text { factors }\end{array}$} & [5] & Cooperation of service providers & 0.431 & 0.246 & 0.189 & 0.135 & 0.252 & 0261 & 0.248 & 0.238 & 0.233 & 0.233 & 0.275 & 0.259 \\
\hline & & [6] & Public-private or state property & 0.579 & 0.172 & 0.104 & 0.145 & 0.227 & 0.309 & 0.214 & 0.249 & 0.241 & 0.249 & 0.264 & 0.246 \\
\hline \multirow{2}{*}{ [4] } & \multirow{2}{*}{$\begin{array}{l}\text { Ecological } \\
\text { factors }\end{array}$} & [7] & $\begin{array}{l}\text { Reduction in environmental } \\
\text { pollution }\end{array}$ & 0.661 & 0.209 & 0.077 & 0.053 & 0.233 & 0.271 & 0.241 & 0.255 & 0.240 & 0.216 & 0.278 & 0.266 \\
\hline & & {$[8]^{\mathrm{E}}$} & $\begin{array}{l}\text { Environmental impact on goods in } \\
\text { the terminal, and vice versa }\end{array}$ & 0.417 & 0.274 & 0.190 & 0.119 & 0.244 & 0.259 & 0.251 & 0.246 & 0.248 & 0.224 & 0.280 & 0.248 \\
\hline \multirow{2}{*}{ [5] } & \multirow{2}{*}{ IT factors } & [9] & Advanced IT systems & 0.652 & 0.212 & 0.081 & 0.055 & 0.254 & 0.268 & 0.240 & 0.238 & 0.247 & 0.230 & 0.281 & 0.242 \\
\hline & & [10] & Container tracking systems & 0.663 & 0.187 & 0.097 & 0.053 & 0.253 & 0.263 & 0.247 & 0.236 & 0.228 & 0.224 & 0.301 & 0.247 \\
\hline \multirow{2}{*}{ [6] } & \multirow{2}{*}{$\begin{array}{l}\text { Economic } \\
\text { factors }\end{array}$} & [11] & $\begin{array}{c}\text { Infrastructure construction } \\
\text { investments }\end{array}$ & 0.642 & 0.202 & 0.066 & 0.090 & 0.265 & 0.280 & 0.232 & 0.224 & 0.244 & 0.222 & 0.288 & 0.247 \\
\hline & & [12] & Facilitating international trade & 0.678 & 0.175 & 0.057 & 0.089 & 0.239 & 0.272 & 0.244 & 0.245 & 0.232 & 0.228 & 0.294 & 0.246 \\
\hline \multirow{2}{*}{ [7] } & \multirow{2}{*}{$\begin{array}{l}\text { Legal and } \\
\text { regulatory } \\
\text { factors }\end{array}$} & [13] & Fitting into spatial-urban plans & 0.516 & 0.241 & 0.139 & 0.103 & 0.233 & 0.295 & 0.251 & 0.222 & 0.183 & 0.172 & 0.402 & 0.242 \\
\hline & & [14] & $\begin{array}{l}\text { Fitting into the railway transport } \\
\text { development policy of the EU }\end{array}$ & 0.708 & 0.165 & 0.055 & 0.072 & 0.252 & 0.289 & 0.230 & 0.229 & 0.172 & 0.147 & 0.422 & 0.258 \\
\hline \multirow{4}{*}{ [8] } & \multirow{4}{*}{$\begin{array}{l}\text { Specific } \\
\text { factors }\end{array}$} & [15] & $\begin{array}{c}\begin{array}{c}\text { Connection to the EU TEN-T } \\
\text { network }\end{array} \\
\end{array}$ & 0.632 & 0.220 & 0.062 & 0.086 & 0.250 & 0.263 & 0.253 & 0.234 & 0.219 & 0.207 & 0.317 & 0.257 \\
\hline & & [16] & Impact on regional development & 0.559 & 0.210 & 0.126 & 0.106 & 0.246 & 0.264 & 0.252 & 0.238 & 0.205 & 0.234 & 0.283 & 0.278 \\
\hline & & & & 0.578 & 0.218 & 0.109 & 0.096 & 0.246 & 0.271 & 0.245 & 0.238 & 0.227 & 0.218 & 0.299 & 0.255 \\
\hline & & & & 1. & 2. & 3. & 4. & 2. & 1. & 3. & 4. & 3. & 4. & 1. & 2. \\
\hline
\end{tabular}




\subsection{Selected Dry Port Locations for Seaport Rijeka}

Figure 19 shows the selected optimal locations of close, medium-distance and distant dry port for Seaport Rijeka. According to the assessments and results obtained by the AHP methodology for selecting the dry port location of the Seaport Rijeka (Figures 13, 15 and 17), it can be concluded that the optimal location of the close dry port would be in Miklavlje, the optimal location of medium-distance dry port would be in Velika Gorica, and the optimal location of a distant dry port would be in Vinkovci.

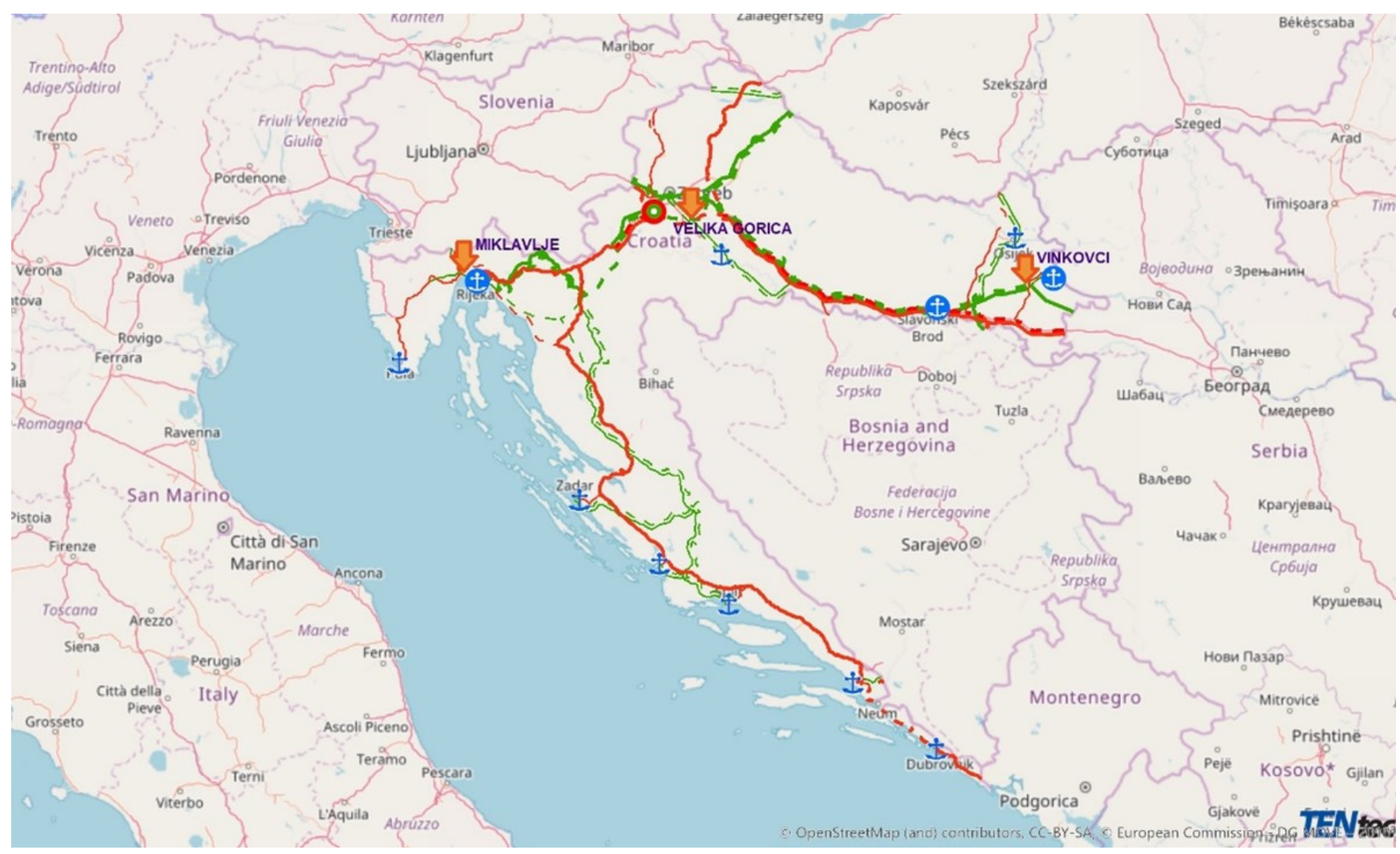

Figure 19. Selected dry port locations for Seaport Rijeka in the road and railway EU TEN-T network.

Figure 20 shows three possible dry port locations for Seaport Rijeka as well as Seaport Rijeka, and its positions in comparison with strategic transport routes (existing and planned). As shown in Figure 20, the strategic transport routes [14,17,18] include the following:

Establishment of the Adriatic-Ionian Corridor, i.e., the construction of a new highefficiency railway line Trieste-Koper-Rijeka, and further Rijeka-Oštarije-Split-DubrovnikBar-Durrës-Igoumenitsa (-Kalamata);

Connection with TEN-T Baltic-Adriatic, as well as RFC 5 Baltic-Adriatic and RFC 11 Amber, which is possible in two directions: Rijeka-Šapjane-Pivka and in the direction Zagreb-Pragersko (existing direction Zagreb-Zidani Most);

Inclusion of Zadar, Šibenik, and Split in the network of TEN-T and RFC corridors, which is possible through the Baltic-Adriatic corridor branch on the route Pragersko (Zidani Most)- Zagreb-Ogulin-Knin-Zadar; Knin-Perković-Šibenik, Knin-Split.

Connecting the port of Ploče, as well as Bosnia and Herzegovina, is possible in the network of TEN-T and RFC corridors by connecting to the Mediterranean Corridor and RFC 10 Alps-Western Balkans in the direction of Ploče-Sarajevo-Doboj-Strizivojna-Vrpolje; Tuzla-Brčko-Vinkovci-Vukovar; DobojBanja Luka-Sisak-Zagreb. 


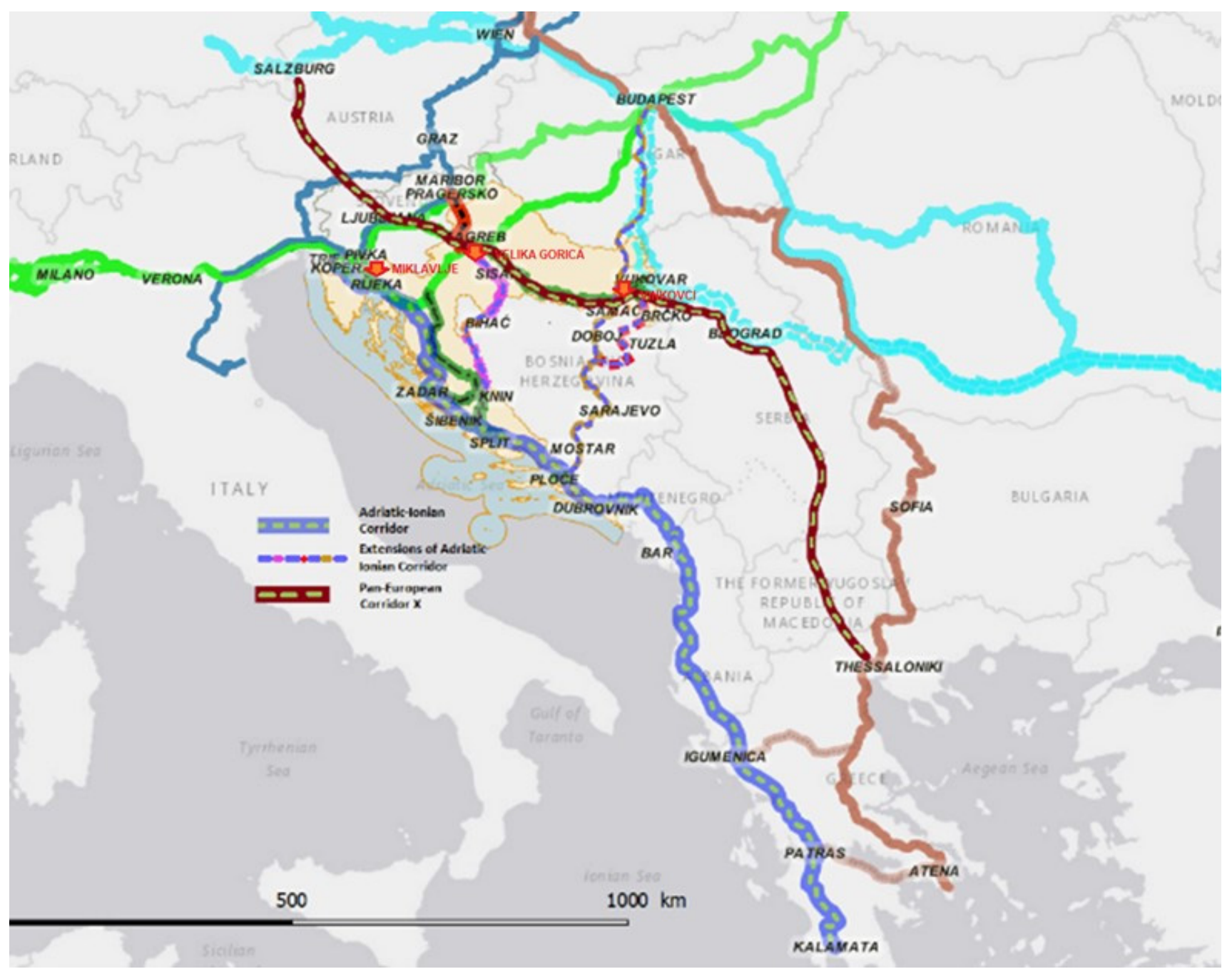

Figure 20. Croatian strategic transport routes (existing and planned).

\section{Discussion}

Seaport Rijeka is Croatia's largest seaport. Its main activities involve transport and handling of cargo, with a focus on increasing the quality of services and the competitiveness of the transport routes in Croatia and EU. As an integral part of the TEN-T transport network and corridors, Seaport Rijeka is in an excellent position to take advantage of its location. Due to increasing demand in container traffic, Seaport Rijeka is searching for solutions to expand. One of the possible solutions is establishing a dry port. Thanks to its geographical position, spatial potential and direct connection to European transport routes, a new dry port would provide the opportunity to develop various projects to a wide range of investors, especially those coming from areas of southern Germany, Austria, Switzerland, Italy, Czech Republic, Slovakia, Hungary, Slovenia, Serbia, Bosnia and Herzegovina, which gravitate around Rijeka Seaport and use the Rijeka transport route.

The focus of this paper was to determine the optimal location of a dry port serving Seaport Rijeka. Three groups of alternatives were defined, due to justification of influential factors impacting establishment of a dry port. Groups of alternatives were defined according to the well-known concept of building dry ports, i.e., group of alternatives to determine close dry port, group of alternatives to determine medium-distance dry port, and group of alternatives to determine distant dry port to serve Seaport Rijeka. The AHP methodology was used to determine the optimal dry port location of the Seaport Rijeka, i.e., the Expert Choice software tool. Before conducting the analysis, the survey was conducted in the way that each expert graded (in his/her own opinion) the factors and alternatives with 
the scale from 1 to 9 . The group of experts consists of 10 experts in the field of maritime transport, intermodal transport and transport and traffic technology. Surveys were conducted anonymously, and upon receiving the results of the survey, they were inserted in the Expert Choice software to conduct the analysis. The results of the analysis were obtained according to the survey results. The hierarchical AHP decision-making models for ranking possible alternatives of selecting optimal dry port location are generated for each group of alternatives (close, medium-distance, distant dry port). For selection of the close dry port location, the examined alternatives were Miklavlje, Škrljevo, Lokve and Delnice. For selection of medium-distance dry port location, the examined alternatives were Zagreb-RTZ, Velika Gorica, Dugo Selo, Ivanić Grad. For selection of the distant dry port location, the examined alternatives were Slavonski Brod, Osijek, Vinkovci, Vukovar. According to the assessments and results obtained by the AHP methodology for selecting optimal dry port location of the Seaport Rijeka for each group of alternatives (close, medium-distance, distant dry port), the optimal location of the close dry port would be in Miklavlje, the optimal location of medium-distance dry port would be in Velika Gorica, and the optimal location of a distant dry port would be in Vinkovci.

The Miklavlje Logistics Centre is located in the Municipality of Matulji, about $17 \mathrm{~km}$ west of the city of Rijeka, next to the Rijeka-Rupa motorway (on the Croatian-Slovenian border), the state road in the same direction and along the Rijeka-Ljubljana railway. The development of the logistics center is planned on an area of 158.5 hectares, with the possibility of further expansion, depending on future requirements [54].

Establishment of a medium-distance dry port terminal is determined in the vicinity of City of Zagreb, in Velika Gorica. The advantage of Velika Gorica is its geostrategic position and the fact that it is located on two rail freight corridors, the Mediterranean and the Alpine-Western Balkan [14,55]. Most of the cargo that has a destination in the countries of the European Union and is brought to the Rijeka Seaport by ship passes through Zagreb Area on its way [2].

The former X Pan-European Railway Corridor, today's Alpine-Western Balkan Rail Freight Corridor, runs through the City of Vinkovci. The proximity of the Danube (TEN-T corridor Rhine-Danube) and the route of the state road D2 along with it, and the highway Zagreb-Lipovac (former X Pan-European Corridor) influenced the formation of a significant transversal road connection that passes through the City of Vinkovci [1,55]. One of the largest railway hubs on the Croatian railways network is located in Vinkovci. The railway hub consists of a passenger and a freight terminal. The freight terminal consists of 50 tracks classified into four groups [9]. The advantage of the city of Vinkovci is that its transport routes, unlike Zagreb and Miklavlje, are not oriented to the directions of Western Europe, but also to the directions of Eastern and South-Eastern Europe, which are also used to transport goods unloaded in the Rijeka Seaport, primarily in the direction of the OrientEast-Med Corridor via Vukovar and RFC 10 to Thessaloniki [2,56].

In this paper, optimal locations for the establishment of close, medium-distance, and distant dry port for Seaport Rijeka were determined, with respect to a wide range of influential factors. The analysis results suggest that the optimal locations for establishing the new dry port are in Miklavlje, Velika Gorica and Vinkovci, which also coincides with the strategic plans for transport route development in Croatia.

The construction of a dry port that would serve Rijeka Seaport (either close, medium distance, distant or combination) would be profitable in terms of full connection and inclusion of the Republic of Croatia in the EU transport network TEN-T, introduction of railways instead of roads, which would ensure reduction in air, water and soil pollution, speed up the process of container transport and compliance with regulatory requirements, and, most importantly, would increase the capacity of the seaport, relieve seaport of congestion and ensure the flow of goods more evenly and efficiently.

Author Contributions: Conceptualization, J.B., I.L., D.B., S.S., V.R. and J.P.Š.; methodology, J.B., I.L., D.B., S.S., V.R. and J.P.Š.; software, J.B., I.L., D.B., S.S., V.R. and J.P.Š.; validation, J.B., I.L., D.B., S.S., V.R. and J.P.Š.; formal analysis, J.B., I.L., D.B., S.S., V.R. and J.P.Š.; investigation, J.B., I.L., D.B., S.S., 
V.R. and J.P.Š.; resources, J.B., I.L., D.B., S.S., V.R. and J.P.Š.; data curation, J.B., I.L., D.B., S.S., V.R. and J.P.Š.; writing-original draft preparation, J.B., I.L., D.B., S.S., V.R. and J.P.Š.; writing-review and editing, J.B., I.L., D.B., S.S., V.R. and J.P.Š.; visualization, J.B., I.L., D.B., S.S., V.R. and J.P.Š.; supervision, J.B., I.L., D.B., S.S., V.R. and J.P.Š.; project administration, J.B., I.L., D.B., S.S., V.R. and J.P.Š.; funding acquisition, J.B., I.L., D.B., S.S., V.R. and J.P.Š. All authors have read and agreed to the published version of the manuscript.

Funding: This research received no external funding.

Institutional Review Board Statement: Not applicable.

Informed Consent Statement: Not applicable.

Data Availability Statement: Not applicable.

Conflicts of Interest: The authors declare no conflict of interest.

\section{References}

1. Trans-European Transport Network (TEN-T). Available online: https://ec.europa.eu/transport/sites/transport/files/themes/ infrastructure/ten-t-guidelines/corridors/doc/ten-t-corridor-map-2013.pdf (accessed on 3 March 2020).

2. Lovrić, I.; Bartulović, D.; Viduka, M.; Steiner, S. Simulation analysis of seaport rijeka operations with established dry port. Sci. J. Marit. Res. 2020, 34, 129-145. [CrossRef]

3. Black, J.; Roso, V.; Marušić, E.; Brnjac, N. Issues in dry port location and implementation in metropolitan areas: The case of Sydney, Australia. Trans. Marit. Sci. 2018, 7, 41-50. [CrossRef]

4. Cullinane, K.; Wilmsmeier, G. The contribution of the dry port concept to the extension of port life cycles. In Handbook of Terminal Planning; Springer: New York, NY, USA, 2011.

5. Hanaoka, S.; Regmi, M.B. Promoting intermodal freight transport through the development of dry ports in Asia: An environmental perspective. Int. Assoc. Traffic Saf. Sci. Res. 2011, 35, 16-23. [CrossRef]

6. Rogić, K.; Rožić, T.; Kolarić, G. Functionality of logistics distribution centers as a inland port terminal (dry port terminals)—Case study city of Zagreb. In Proceedings of the Conference of Planning and Development of Sustainable Transport System, Zagreb, Croatia, 21-23 October 2013.

7. Cezar-Gabriel, C. Performance assessment in operating dry ports. Annals of the university of Oradea. Econ. Sci. Ser. 2010, 19, 934-938.

8. Crainic, T.G.; Dell'Olmo, P.; Ricciardi, N.; Sgalambro, A. Modeling dry-port-based freight distribution planning. Transp. Res. Part C Emerg. Technol. 2015, 55, 518-534. [CrossRef]

9. Dragović, B.; Tzannatos, E.; Park, N.K. Simulation modelling in ports and container terminals: Literature overview and analysis by research field, application area and tool. Flex. Serv. Manuf. J. 2017, 29, 4-34. [CrossRef]

10. Dundović, Č.; Hess, S.; Šantić, L. Load and capacity calculation of the container terminal of the port of Ploče. J. Marit. Res. 2006, 20, 79-95. (In Croatian)

11. Mlinarić, T.J.; Rogić, K.; Rožić, T. Methodology for determining dry port system transport network-Case study port of RijekaZagreb. In DAAAM International Scientific Book; DAAAM International Vienna: Vienna, Austria, 2011; pp. 133-146.

12. TEN-T Days-Croatia's Position in the European Union Transport Network. Available online: https://mmpi.gov.hr/print.aspx? id=16552\&url=print (accessed on 2 March 2020).

13. Jugović, T.P.; Baričević, H.; Karleuša, B. Multi-criteria optimization of competitiveness of the Pan-European corridor V 8 competitiveness. Promet-Traffic Transp. 2006, 18, 189-195. (In Croatian)

14. Transport Development Strategy of the Republic of Croatia (2017-2030). Available online: https://vlada.gov.hr/UserDocsImages / ZPPI/Strategije/MMPI\%202017-2030\%20STRAT\%20PROM\%20RZV\%20RH\%2025-8_17.pdf (accessed on 2 May 2020). (In Croatian)

15. Božičević, J. Traffic corridors between central Danube and Adriatic region on territory of Croatia. Promet 1996, 5, 1-5.

16. Božičević, J. Status and Future of Croatian Railways; Croatian Government: Zagreb, Croatia, 1996. (In Croatian)

17. Božičević, J.; Perić, T. Baltic-Adriatic transport corridors-Conceptual settings for traffic network optimization. Ekon. Pregl. 2005, 56, 185-203. (In Croatian)

18. Steiner, S. Valorization of the Intermodal Logistics Corridor Ploče-Mostar-Sarajevo-Vukovar (Central Adriatic-Danube); Croatian Academy of Sciences and Arts: Zagreb, Croatia, 2017. (In Croatian)

19. Seaport Rijeka, Management Presentation. Available online: www.lukarijeka.hr/Data/Files/194_201506081251975/LKRI.pdf (accessed on 5 April 2020).

20. Seaport Rijeka, Financial Reports. Available online: https:/ /lukarijeka.hr/financijska-izvjesca/ (accessed on 21 June 2020).

21. Lovrić, I.; Bartulović, D.; Steiner, S. Concept of the decision-making model for establishment of dry port on the sample of Rijeka seaport. Our Sea 2020, 67, 232-243. [CrossRef]

22. Ballis, A.; Golias, J. Comparative evaluation of existing and innovative rail-road freight transport terminals. Transp. Res. Part A Policy Pract. 2002, 36, 593-611. [CrossRef] 
23. Bergqvist, R.; Falkemark, G.; Woxenius, J. Establishing intermodal terminals. World Rev. Intermodal Transp. 2010, 3, $285-302$. [CrossRef]

24. Rodrigue, J.P.; Notteboom, T. Dry ports in European and North American intermodal rail systems: Two of a kind? Res. Transp. Bus. Manag. 2012, 5, 4-15. [CrossRef]

25. Roso, V. Emergence and significance of dry ports. Balt. Transp. J. 2010, 38, 44-45.

26. Roso, V.; Lumsden, K. Review of dry ports. Marit. Econ. Logist. 2010, 12, 196-213. [CrossRef]

27. Roso, V. Sustainable intermodal transport via dry ports-Importance of directional development. World Rev. Intermodal Transp. Res. 2013, 4, 140-156. [CrossRef]

28. Bask, A.; Roso, V.; Andersson, D.; Hämäläinen, E. Development of seaport-dry port dyads: Two cases from Northern Europe. J. Transp. Geogr. 2014, 39, 85-95. [CrossRef]

29. Chen, J.; Fei, Y.; Zhang, F.; Jing, C. Evaluating correlations between a seaport and its dry ports: Case study of Xiamen port in China. Discret. Dyn. Nat. Soc. 2018, 2018, 1-15. [CrossRef]

30. Roso, V.; Woxenius, J.; Lumsden, K. The dry port concept: Connecting container seaports with the hinterland. J. Transp. Geogr. 2009, 17, 338-345. [CrossRef]

31. Shi, X.; Li, H. Developing the port hinterland: Different perspectives and their application to Shenzhen Port, China. Res. Transp. Bus. Manag. 2016, 19, 42-50. [CrossRef]

32. Wang, G.W.; Zeng, Q.; Li, K.; Yang, J. Port connectivity in a logistic network: The case of Bohai Bay, China. Transp. Res. Part E Logist. Transp. Rev. 2016, 95, 341-354. [CrossRef]

33. Wilmsmeier, G.; Monios, J.; Lambert, B. The directional development of intermodal freight corridors in relation to inland terminals. J. Transp. Geogr. 2011, 19, 1379-1386. [CrossRef]

34. Woxenius, J.; Bergqvist, R. Hinterland transport by rail-Comparing the Scandinavian conditions for maritime containers and semi-trailers. In Proceedings of the International Association of Maritime Economists Conference (IAME), Copenhagen, Denmark, 24-26 June 2009; pp. 1-15.

35. Oláh, J.; Nestler, S.; Nobel, T.; Harangi-Rákos, M.; Popp, J. Development of dry ports in Europe. Int. J. Appl. Manag. Sci. 2018, 10, 269-289. [CrossRef]

36. Lovrić, I.; Bartulović, D.; Steiner, S. The influence of dry port establishment on regional development through regional development index. Trans. Marit. Sci. 2020, 9, 293-315. [CrossRef]

37. Woxenius, J.; Roso, V.; Lumsden, K. The dry port concept-Connecting seaports with their hinterland by rail. In Proceedings of the First International Conference on Logistics Strategy for Ports (ICLSP), Dalian, China, 22-26 September 2004.

38. Roso, V. Factors influencing implementation of a dry port. Int. J. Phys. Distrib. Logist. Manag. 2008, 38, 782-798. [CrossRef]

39. Awad Núñez, S.; González-Cancelas, N.; Camarero-Orive, A. Setting of weighting factors influencing the determination of the location of dry ports using a DELPHI methodology. In Proceedings of the 1st International Virtual Scientific Conference, Żylina, Slovakia, 10-14 June 2013.

40. Awad-Núñez, S.; González-Cancelas, N.; Camarero-Orive, A. Application of a model based on the use of DELPHI methodology and multicriteria analysis for the assessment of the quality of the Spanish dry ports location. Procedia Soc. Behav. Sci. 2014, 162, 42-50. [CrossRef]

41. Awad-Núñez, S.; González-Cancelas, N.; Camarero-Orive, A. Quality evaluation of Spanish dry ports location based on Delphi methodology and multicriteria analysis. In Proceedings of the 2nd Electronic International Interdisciplinary Conference, Zilina, Slovakia, 2-6 September 2013; pp. 502-508.

42. Linstone, H.A.; Turoff, M.; Helmer, O. The Delphi Method Techniques and Applications Los Angeles; University of Southern California: Los Angeles, CA, USA, 2002.

43. Saaty, T.L. The Analytic Hierarchy Process, 2nd ed.; RWS Publications: Pittsburg, CA, USA, 1996.

44. Saaty, T.L.; Vargas, L.G. Models, Methods, Concepts \& Applications of the Analytic Hierarchy Process; Kluwer Academic Publisher: Dordrecht, The Netherlands, 2001.

45. The Analytic Network Process. Available online: http://www.iors.ir/journal/article-1-27-en.pdf (accessed on 17 April 2020).

46. Vinovrški, D. Application of Multi-Criteria Analysis Method in Decision Making. Master's Thesis, Faculty of Economics and Tourism, Pula, Croatia, 2016. (In Croatian).

47. Šimunović, L.; Grgurević, I.; Pašagić-Škrinjar, J. Selecting optimal pedestrian crossing using multi-criteria decision-making. Traffic Manag. 2010, 22, 105-116. [CrossRef]

48. Srđević, B.; Srđević, Z.; Zoranović, T. PROMETHEE, TOPSIS and CP in multi-criteria decision-making in agriculture. Letop. Naučnih Rad. 2002, 26, 5-23. (In Croatian)

49. Deluka-Tibljaš, A.; Karleuša, B.; Dragičević, N. Review of the application of multi-criteria analysis methods in making decisions on transport infrastructure. Građevinar 2013, 65, 619-631. (In Croatian)

50. Hunjak, T.; Jakovčević, D. Multi-criteria models for ranking and comparing banks. In Proceedings of Faculty of Economics; Faculty of Economic: Belgrade, Serbia, 2013. (In Croatian)

51. Arslan, T. A hybrid model of fuzzy and AHP for handling public assessments on transportation projects. Transportation 2009, 36, 97-112. [CrossRef]

52. Roso, V. Emergence and significance of dry ports-The case of the port of Göteborg. World Rev. Intermodal Transp. Res. 2009, 2, 296-310. [CrossRef] 
53. Do, N.; Nam, K.; Le, Q. A consideration for developing a dry port system in Indochina area. Marit. Policy Manag. 2011, 38, 1-9. [CrossRef]

54. Spatial Plan of the Municipality of Matulji. Available online: http:/ / matulji.hr/pocetna/prostorni-planovi/ (accessed on 2 May 2020).

55. Rail Freight Corridors (RFCs) Map. Available online: http:/ /rne.eu/wp-content/uploads/RFC-MAP-2017.pdf (accessed on 2 May 2020).

56. Master Plan of the City of Vinkovci for Traffic. Available online: http://viavinkovci.hr/wp-content/uploads/2019/11/Masterplan-Grada-Vinkovaca-za-promet.pdf (accessed on 2 May 2020). 